\title{
Mineralogical and geochemical studies of secondary mineral assemblages related to deterioration of building materials
}

\author{
Mariola MARSZAŁEK ${ }^{1, *}$, Krzysztof DUDEK ${ }^{1}$, Adam GAWE ${ }^{1}$ and Jerzy CZERNY ${ }^{1}$ \\ 1 AGH University of Science and Technology, Faculty of Geology, Geophysics and Environmental Protection, \\ al. A. Mickiewicza 30, 30-059 Kraków, Poland
}

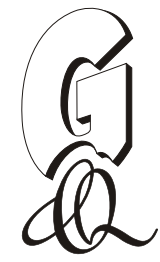

\begin{abstract}
Marszałek, M., Dudek, K., Gaweł, A., Czerny, J., 2019. Mineralogical and geochemical studies of secondary mineral assemblages related to deterioration of building materials. Geological Quarterly, 63 (4): 683-698, doi: 10.7306/gq.1494

The study was aimed at mineralogical and geochemical characteristics of secondary phases related to deterioration of historic building materials. The investigations, carried out in the Holy Trinity Basilica in Kraków, Poland, focused on the southern facade of the 17th-century Myszkowskis Chapel, built of the Miocene Pińczów limestone. Lower part of the facade is covered with a cement render, and the exposed foundations are made of Jurassic limestone and Cretaceous sandstone, both of local origin from the Kraków region and neighbouring Carpathians, in the form of irregular blocks bound with a cement mortar. The wall surface exhibits clear signs of damage; from dark grey soiling and scaling to efflorescences. Sampled materials, deteriorated, altered crusts and efflorescences were analysed with optical and scanning electron microscopy, X-ray diffraction, and Raman microspectroscopy methods. The secondary minerals distinguished include abundant gypsum $\mathrm{CaSO}_{4} \cdot 2 \mathrm{H}_{2} \mathrm{O}$, less common thenardite $\mathrm{Na}_{2} \mathrm{SO}_{4}$ (and/or mirabilite $\mathrm{Na}_{2} \mathrm{SO}_{4} \cdot 10 \mathrm{H}_{2} \mathrm{O}$ ), aphthitalite $(\mathrm{K}, \mathrm{Na})_{3} \mathrm{Na}\left(\mathrm{SO}_{4}\right)_{2}$, darapskite $\mathrm{Na}_{3}\left(\mathrm{SO}_{4}\right)\left(\mathrm{NO}_{3}\right) \cdot \mathrm{H}_{2} \mathrm{O}$, ettringite $\mathrm{Ca}_{6} \mathrm{Al}_{2}\left(\mathrm{SO}_{4}\right)_{3}(\mathrm{OH})_{12} \cdot 26 \mathrm{H}_{2} \mathrm{O}$, monosulphite $\mathrm{Ca}_{4} \mathrm{Al}_{2} \mathrm{O}_{6} \mathrm{SO}_{3} \cdot 11 \mathrm{H}_{2} \mathrm{O}$, as well as scarce nitre $\mathrm{KNO}_{3}$, nitratine $\mathrm{NaNO}_{3}$ and halite $\mathrm{NaCl}$. Gypsum usually forms surface crusts and fills the pores inside some materials. The efflorescences, sampled from the exposed foundations, consisted of thenardite and/or mirabilite, aphthitalite and darapskite, whereas ettringite and monosulphite were connected with cement renders. Traces of nitre, nitratine and halite were detected at various elements of the chapel facade and foundations. The origin of the salts is related to composition and physicochemical properties of the building materials, as well as to anthropogenic factors.
\end{abstract}

Key words: stone deterioration, secondary salts, aphthitalite, darapskite.

\section{INTRODUCTION}

Crystallization of secondary minerals, first of all salts, being the most efficient deterioration process in porous materials, both natural and artificial ones, may substantially contribute to damaging of building materials. The most important damaging factor is crystallization pressure during salt precipitation; producing stress in the substrate, it results in the formation of cracks and lack of cohesion between components of the materials (Flatt et al., 2007). The process of damage is a function of both the solution saturation ratio and the place of the crystallization. Crystals can grow either in confined spaces, e.g. in pores or as subflorescences, or in unconfined space as efflorescences. Therefore, the pore-size distribution of building material is very important in the deterioration processes (Rodriguez-Navarro and Doehme, 1999; Benavente, 2011). The chemical composition of secondary salts depends in general on natural and anthropogenic, internal and external factors (Manecki et al., 1997; Marszałek, 2016). They include, in partic-

\footnotetext{
* Corresponding author, e-mail: mmarszal@agh.edu.pl
}

Received: January 28, 2019; accepted: June 24, 2019; first published online: November 25, 2019 ular, composition of substratum, climatic and topographic conditions, animal and microorganism activities, capillary rise of ground and soil waters, pollution of the atmosphere, as well as chemicals used for conservation processes. Typical secondary salts forming in historical structures in polluted atmosphere are sulphates, chlorides, and nitrates of calcium, magnesium, sodium and potassium. Their presence in deteriorated building materials and monuments, taking into account various aspects, is reported by numerous authors (e.g., Labus, 1998; Del Monte et al., 2001; Słaby et al., 2001; Cardell et al., 2003; Sabbioni, 2003; Wilczyńska-Michalik, 2004; De Belie, 2010; Kramar et al., 2010; Grossi et al., 2011; Török et al., 2011; Marszałek et al., 2014; Morillas et al., 2016; Prikryl et al., 2017). Secondary salts are more soluble than the parent minerals and are subsequently involved in dissolution-recrystallization cycles, then acting as the agents in salt weathering processes. Among them, the salts that exist in anhydrous forms and/or can crystallize as various hydrates are most deleterious. Examples are anhydrous sodium sulphate $\mathrm{Na}_{2} \mathrm{SO}_{4}$ - thenardite and decahydrous sodium sulphate $\mathrm{Na}_{2} \mathrm{SO}_{4} \cdot 10 \mathrm{H}_{2} \mathrm{O}$ - mirabilite (Steiger and Asmussen, 2008). Also incongruently soluble double salts [e.g., darapskite $\mathrm{Na}_{3}\left(\mathrm{SO}_{4}\right)\left(\mathrm{NO}_{3}\right) \cdot \mathrm{H}_{2} \mathrm{O}$, aphthitalite $(\mathrm{K}, \mathrm{Na})_{3} \mathrm{Na}\left(\mathrm{SO}_{4}\right)_{2}$, bloedite $\mathrm{Na}_{2} \mathrm{Mg}\left(\mathrm{SO}_{4}\right)_{2} \cdot 4 \mathrm{H}_{2} \mathrm{O}$ ], of complex crystallization behaviour depending on relative humidity and solution composition, may have a great damage potential (Linnow et al., 2013; Lindström et al., 2015). 

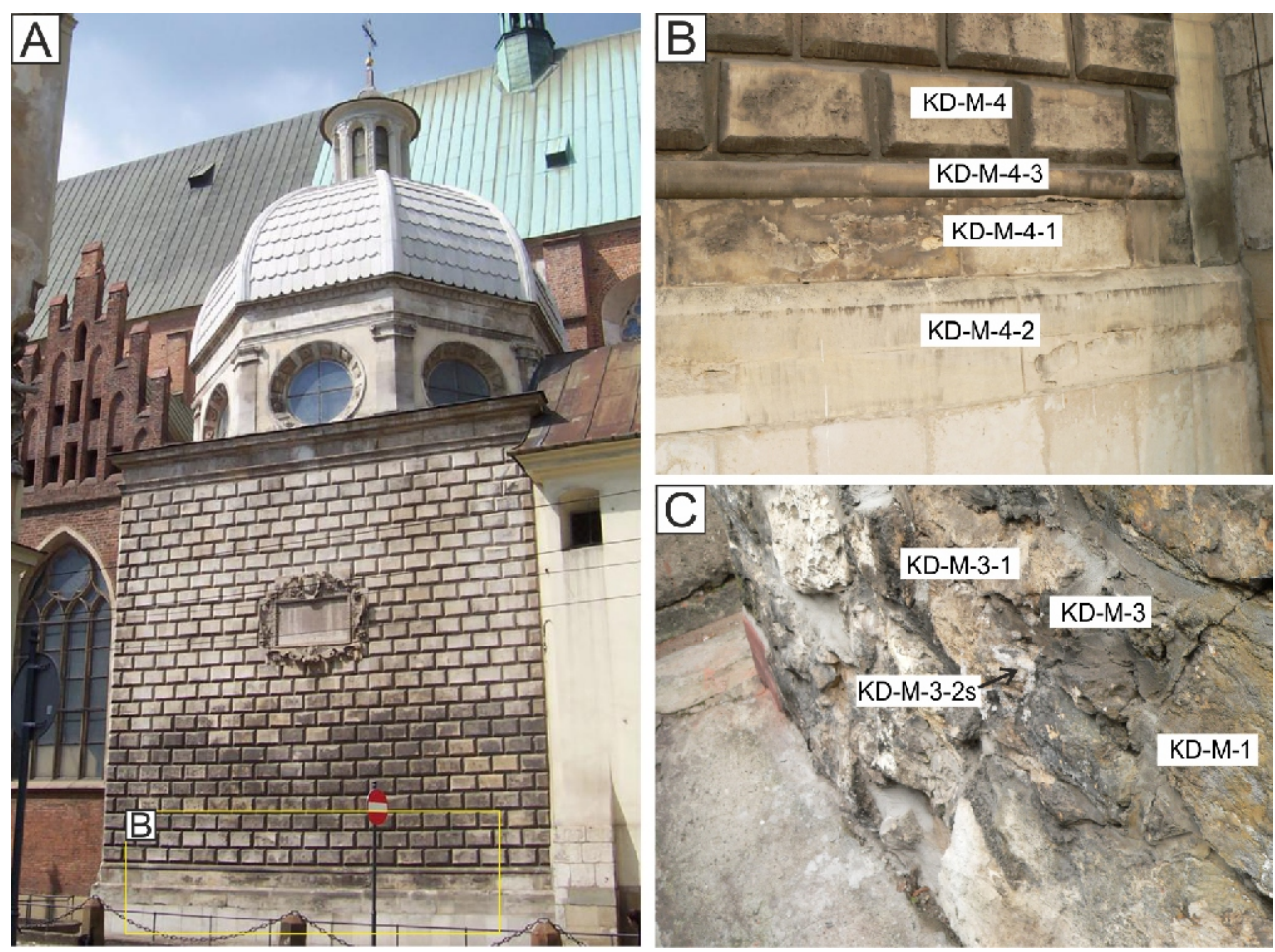

Fig. 1. Elevation of the Myszkowskis Chapel of the Holy Trinity Basilica of the Dominican Order in Kraków (A), and the sampling sites - rusticated wall and elements below (B), exposed part of the foundations (C)

The samples represent respectively: KD-M-4 - rusticated limestone blocks; KD-M-4-1 - limestone-block belt below the shaft; KD-M-4-2 - lower cement-rendered part of the elevation; KD-M-4-3 - shaft below the rusticated fasade; KD-M-1 - subwall sandstone blocks; KD-M-3 - cement mortar from the subwall; KD-M-3-1 - subwall limestone blocks; KD-M-3-2s - salt efflorescences. Area presented in C is located beneath the pavement level, below the area marked as B. Photos by K. Bałaga

Optical and scanning electron microscopy, X-ray diffraction, and Raman microspectroscopy have been used to identify the secondary salts occurring in deteriorated architectonical elements of the Basilica of Holy Trinity; a 13th century church and monastery of the Dominican Order in Kraków, Poland. Studies presented in this paper focused on the southern facade of the Myszkowskis Chapel, built of various materials in the first half of the 17 th century. The characteristic rusticated wall of the facade is made of Miocene limestone blocks, covered with a cement render in its lower part. The exposed foundations are made of irregular fragments of grey sandstones and bright limestones, bound with and partly replaced by a cement. The Upper Cretaceous Istebna sandstones must have been quarried in the Polish Flysch Carpathians, foothills of the mountains, a few tens of kilometres S of Kraków. The Upper Jurassic limestones most likely came from quarries in close vicinity, N or NW from the Old Town of Kraków (Górecki and Sermet, 2010). The wall reveals clear signs of damage ranging from dark grey soiling of the surface, scaling to efflorescences. The last ones occur mainly on the border between the limestone blocks and the cement replacements in a part of the foundations.

\section{MONUMENT}

The Basilica of Holy Trinity in Kraków, a vast three-aisled temple, was chosen to be a burial site by many noble families, among others the Myszkowskis family. In the early 17th century, the Myszkowskis Chapel was built on site of the older St. Dominic Chapel, most likely by masonry masters from a work- shop of Santi Gucci from Florence (Italy). Founded by Zygmunt Myszkowski and his brother Alexander, the chapel became the family mausoleum (Bieniarzówna and Małecki, 1984). Facade of the chapel (Fig. 1), with the exposed foundation plaque, was made of regular blocks of Middle Miocene (Lower Badenian) lithothamnium limestone, the so-called Pińczów limestone, quarried in and near Pińczów (Carpathian Foredeep, south-central Poland; Grabski and Nowak, 1960; Rajchel, 2004), developed in the form of Mannerist rustication (Dobrowolski, 1978; Rożek, 2009). Rusticated blocks, covering large part of the facade, are underlain by a small architectural element in shape of a shaft, and a belt of rectangular limestone blocks without rustication. The lowest part of the facade wall, down to the pavement level, consists of rectangular bright blocks of various dimensions (Fig. 1A, B). The chapel subwall, below the pavement line, was made of a variety of materials in the form of more or less regular blocks, as well as irregular, sharp-edged pieces of bright compact limestone and grey sandstone, most likely bound with a cement mortar (Fig. 1C). The mortar was applied unevenly, in places covers the stony elements, and in some others forms convex welds. Available sources (Grabski and Nowak, 1957, 1960; Rajchel, 2004) and unpublished conservatory documentations yielded information only about the rusticated Pińczów limestone. No detailed information about the elevation materials or earlier conservation works was encountered.

The alterations observed are represented mainly by stains on the surface, colour changes, black crusts and surface exfoliations. In addition, white fine-crystalline salt efflorescences, particularly distinct on the contacts between the lime- 
List of samples and sampling sites (for details see also Fig. 1)

\begin{tabular}{|c|c|c|c|}
\hline \multicolumn{2}{|c|}{ Samples location } & Sample code & Description and height above/below the pavement [m] \\
\hline \multirow{4}{*}{$\begin{array}{l}\text { Elevation of the } \\
\text { Myszkowskis } \\
\text { Chapel }\end{array}$} & rusticated blocks & KD-M-4 & limestone, $1.3-1.7 \mathrm{~m}$ above the pavement level \\
\hline & $\begin{array}{l}\text { the shaft below the rusticated fa- } \\
\text { cade }\end{array}$ & KD-M-4-3 & $\begin{array}{c}\text { limestone covered in places of cement render; } 1.2 \mathrm{~m} \\
\text { above the pavement level }\end{array}$ \\
\hline & $\begin{array}{l}\text { the belt of stony blocks below } \\
\text { the shaft }\end{array}$ & $\mathrm{KD}-\mathrm{M}-4-1$ & $\begin{array}{l}\text { limestone covered in places of cement render; } 1.1 \mathrm{~m} \text { above } \\
\text { the pavement level }\end{array}$ \\
\hline & $\begin{array}{l}\text { the wall from bright blocks, } \\
\text { just above the pavement level }\end{array}$ & KD-M-4-2 & $\begin{array}{c}\text { limestone covered with several mm thick cement render; } \\
0.5-1.0 \mathrm{~m} \text { above the pavement level }\end{array}$ \\
\hline \multirow{4}{*}{$\begin{array}{l}\text { Subwall of the } \\
\text { chapel below the } \\
\text { pavement level }\end{array}$} & cement mortar & KD-M-3 & cement sandy mortars; $0.7 \mathrm{~m}$ below the pavement level \\
\hline & \multirow{2}{*}{ stone blocks } & KD-M-3-1 & limestone; $0.5-1.0 \mathrm{~m}$ below the pavement level \\
\hline & & KD-M-1 & sandstone; $0.5 \mathrm{~m}$ below the pavement level \\
\hline & salt efflorescences & KD-M-3-2s & $\begin{array}{c}\text { on the border between the limestone blocks and the } \\
\text { cement replacements }\end{array}$ \\
\hline
\end{tabular}

stone surface and the cement mortar (Fig. 1C), could be observed in the lower part of the subwall.

\section{MATERIALS AND METHODS}

Samples for the studies were taken from the elevation and subwall of the Myszkowskis Chapel (Fig. 1 and Table 1). They represent architectonical elements made of various materials distinguished macroscopically. These are rustications (samples labelled KD-M-4), the shaft below the rusticated facade (samples labelled KD-M-4-3), the belt of stony blocks below the shaft (samples labelled KD-M-4-1), and a piece of the wall from bright blocks, just above the pavement level (samples labelled KD-M-4-2). Samples from the subwall below the pavement level represent a cement mortar between stony blocks (samples labelled KD-M-3), limestone blocks (samples labelled KD-M-3-1), sandstone blocks (samples labelled KD-M-1), and salt efflorescences (samples labelled KD-M-3-2s).

Because of restrictions concerning sampling of historic objects (size and amount of samples), the pore structure analysis with the mercury-intrusion porosimetry method could not be made for two very small samples from the shaft below the rusticated facade (KD-M-4-3) and blocks below the shaft (KD-M-4-1). Microscopic analysis of these samples demonstrated that they proved to be highly similar to the rusticated elevation sample (KD-M-4).

The samples were taken in 2017 at conservatory works in due course, by courtesy of the Monastery authorities and $\mathrm{Mr}$ Bartłomiej Polczyński.

The petrographic characteristics of stones and other building materials were based on analysis of thin sections cut perpendicularly to the outer layers of the samples (optical microscopy in the transmitted light, OM), using an Olympus BX-51 instrument coupled with an Olympus DP-12 digital camera. The porosity and pore-size distributions were analysed with a mercury intrusive porosimeter AutoPore IV 9520 produced by Micromeritics, which operates within the 0.1-413 MPa pressure interval and allows determining pores within the 0.003-1000 $\mu \mathrm{m}$ range.

The elemental analyses of mineral components, mainly these of secondary origin, their morphology and microstructure of the materials were studied using a FEI 200 Quanta FEG scanning electron microscope with an EDS/EDAX spectrome- ter. The maximum excitation voltage was $20 \mathrm{kV}$, and a low vacuum mode (the pressure $60 \mathrm{~Pa}$ ) was used. The samples included polished thin sections, broken, sharp surfaces of weathered materials, and efflorescences themselves.

Phase compositions of the samples were determined using the X-ray powder diffraction method (XRPD) with a Rigaku MiniFlex 600 instrument. The measurement conditions were as follows: $\mathrm{CuK}_{\alpha}$ anode, generator settings $40 \mathrm{kV}$ and $15 \mathrm{~mA}$, recording range $3-70^{\circ} 2 \Theta$, step size $0.05^{\circ}$, counting time $1 \mathrm{sec} / \mathrm{step}$. The results were processed with XRAYAN software using a diffraction $X$-ray pattern database of the International Centre for Diffraction Data (the Powder Diffraction File PDF-4, 2013).

Composition of secondary mineral phases was also determined using Raman microspectroscopy. The spectra were recorded with a Thermo Scientific DXR Raman microscope with a 900 grooves $/ \mathrm{mm}$ grating and a CCD detector. The Olympus

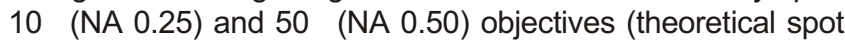
sizes $2.1 \mu \mathrm{m}$ and $1.1 \mu \mathrm{m}$, respectively) were used. Excitation was activated with a $532 \mathrm{~nm}$ diode laser with maximum power of $10 \mathrm{~mW}$. The laser power varied in the $3-10 \mathrm{~mW}$ range and the measurement time from 30 to $300 \mathrm{~s}$, selected appropriately to avoid possible thermal decomposition of the samples and to obtain the best quality of spectra. Their identification was performed using in-house and RRUFF Raman Minerals spectral libraries, as well as literature data (Hansteen and Burke, 1994; Sadezky et al., 2005; Buzgar et al., 2009; Hamilton and Menzies, 2010; Jentzsch et al., 2012; Prieto-Taboada et al., 2014, 2019).

The cement notation used through the paper is as follows: $\mathrm{A}=\mathrm{Al}_{2} \mathrm{O}_{3}, \mathrm{C}=\mathrm{CaO}, \mathrm{F}=\mathrm{Fe}_{2} \mathrm{O}_{3}, \mathrm{H}=\mathrm{H}_{2} \mathrm{O}, \mathrm{S}=\mathrm{SiO}_{2}$.

\section{RESULTS AND DISCUSSION}

\section{MATERIAL CHARACTERISTICS}

ELEVATION OF THE MYSZKOWSKIS CHAPEL

Samples of rusticated blocks (KD-M-4) and below-the-shaft blocks (KD-M-4-1) represent organogenic limestones with abundant, well-preserved bioclasts characteristic for the Pińczów limestone: red algae of the genus Lithothamnium, bryozoans, foraminifers, including the genus Amphistegina, 

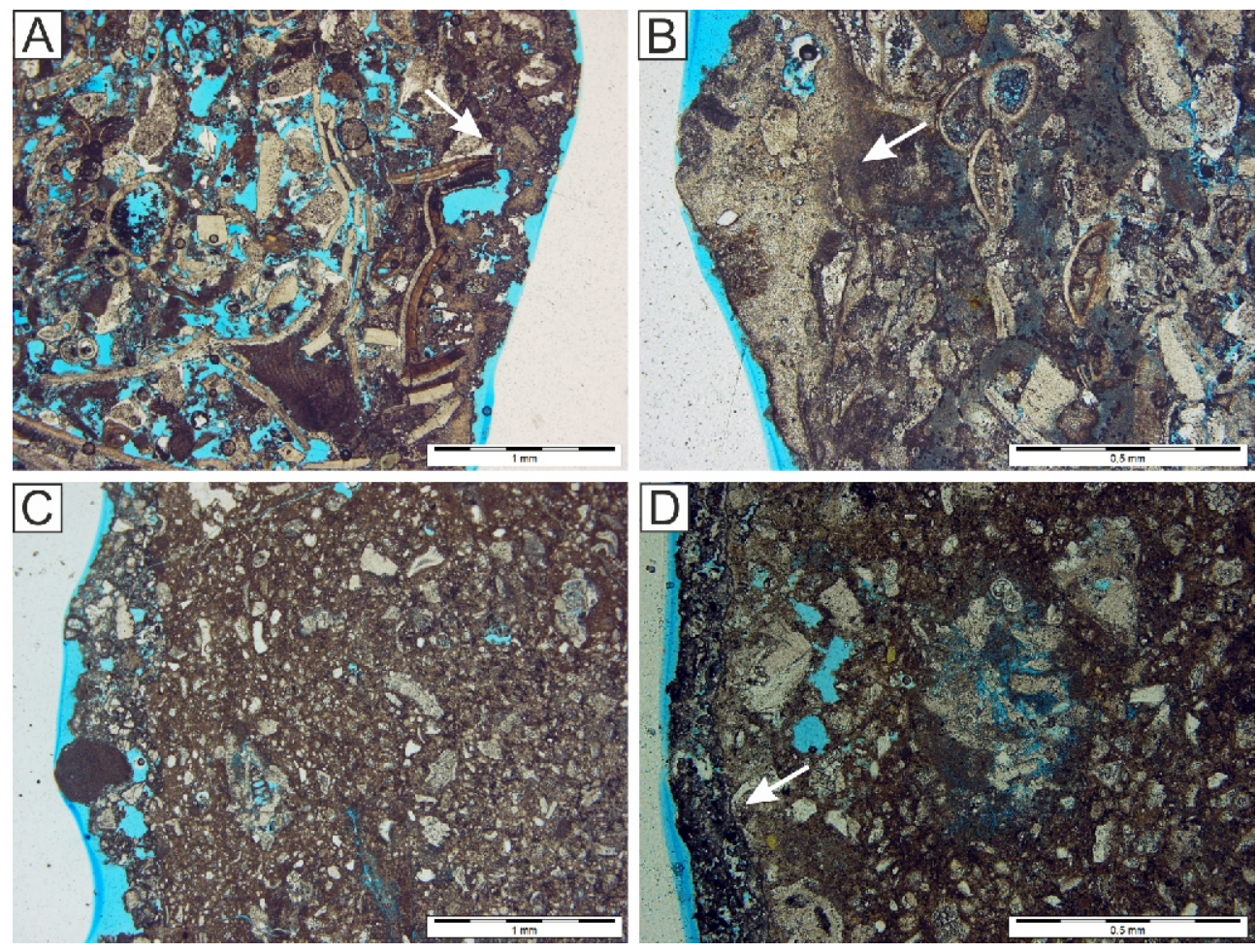

Fig. 2. Microphotographs (plane-polarized light) of the samples taken from the rusticated wall and the elements below

A - KD-M-4 Pińczów limestone; B - KD-M-4-1 Pińczów limestone covered in places with cement render; C - KD-M-4-2 Pińczów limestone covered with cement render; D - KD-M-4-3 Pińczów limestone covered in places with cement render; for detailed sample code explanations see Figure 1 and Table 1; thin sections cut perpendicularly to the outer layers, the arrows indicate crusts of deteriorated materials

and fragments of bivalve shells (Studencki, 1988; Fig. 2A). Elongated and flattened forms are up to $1 \mathrm{~cm}$, whereas round bioclasts are up to $5 \mathrm{~mm}$. Accessory components of these limestones are quartz grains and glauconite aggregates, both up to $0.2 \mathrm{~mm}$ in size. Irregular strikes of secondary semi-opaque iron compounds were observed as well. At the edge of sample KD-M-4-1, discontinuous segments were present, distinctly different from the limestone, enriched in small quartz grains and tiny, submicroscopic matrix components. They could represent a deteriorated cement render cover, ca. $1 \mathrm{~mm}$ in thickness. However, the available literature and unpublished conservatory documentation (Grabski and Nowak, 1960) are lacking any information on that. Analysis of surface distribution maps (Ca, $\mathrm{Si}$ and Al primarily) of samples KD-M-4 and KD-M-4-1 (in cross-sections perpendicular to the sample surfaces; Fig. 3A, $B)$ reveals quantitative zonal diversity of concentration of these elements in sample KD-M-4-1. Its outer zone is clearly enriched in Si and Al. In a microscopic image (OM) of both samples, a discontinuous outer layer of varying thickness, occasionally reaching several hundred $\mu \mathrm{m}$, were distinguished (Fig. 2A, B). Generally, tiny sharp-edged opaque particles and needle-shaped transparent components of very low interference colours, sometimes isotropic, were observed. Similar components were noted inside the samples as well. The SEM-EDS analysis revealed $\mathrm{Ca}, \mathrm{S}$ and $\mathrm{O}$, which pointed out gypsum $\mathrm{CaSO}_{4} \cdot 2 \mathrm{H}_{2} \mathrm{O}$. The distribution of sulphur in cross-sections perpendicular to the sample surfaces indicates sites of concentration of this element (Fig. 3A, B). In the case of sample KD-M-4-1, the map reveals accumulation of sulphur in the outer zone of the Pińczów limestone, directly below the render layer.
The XRPD phase analyses confirmed the presence of gypsum in both these samples (KD-M-4 and KD-M-4-1). It is undoubtedly a secondary phase related to deterioration of the material in a polluted urban environment. The other phases registered are calcite (predominant component) and quartz; natural components of the architectural elements analysed. However, they may also be present in the cement render (sample KD-M-4-1) and silica-organic resins, possibly used at earlier conservation works. In the case of the Pińczów limestone rustications (KD-M-4), the SEM-EDS analysis revealed abundant tiny grains ( $\mathrm{Si}$ and $\mathrm{O}$ in chemical composition) at the surface, as interstitions between ubiquitous tabular gypsum crystals.

Based on mercury-intrusion porosimetry measurements, sample KD-M-4 is characterized by a high open porosity of $24.66 \%$ and a bulk density of $1.83 \mathrm{~g} / \mathrm{cm}^{3}$. Its pore-size distribution indicates dominance of the pores in two ranges: $10.0-1.0 \mu \mathrm{m}$ that makes up $40.95 \%$, and the pores of $1.0-0.1 \mu \mathrm{m}-30.64 \%$. The pores of $70-10.0 \mu \mathrm{m}$ make up $9.5 \%$, and the pores of $0.1-0.003 \mu \mathrm{m}-18.87 \%(0.1-0.01 \mu \mathrm{m}-16.77 \%$; Fig. 4). The average pore diameter (calculated as a weighted average, with the weight determining the number of pores, and not the percentage of the pore space) is $0.10 \mu \mathrm{m}$, and the total pore area is $5.19 \mathrm{~m}^{2} / \mathrm{g}$. The pore-size distribution is bimodal, with dominance of pores in the ranges of 10.0-1.0 and 1.0-0.1 $\mu \mathrm{m}$. Low threshold diameter $(7 \mu \mathrm{m})$ suggests that the internal movement of solutions through the stone is difficult and inefficient, the permeability is $5.47 \mathrm{mD}$, and the hysteresis effect $-15 \%$.

Microscopic analysis (OM) of samples from the shaft (KD-M-4-3) and bright blocks below (KD-M-4-2) demonstrated that these architectural elements were produced from the 

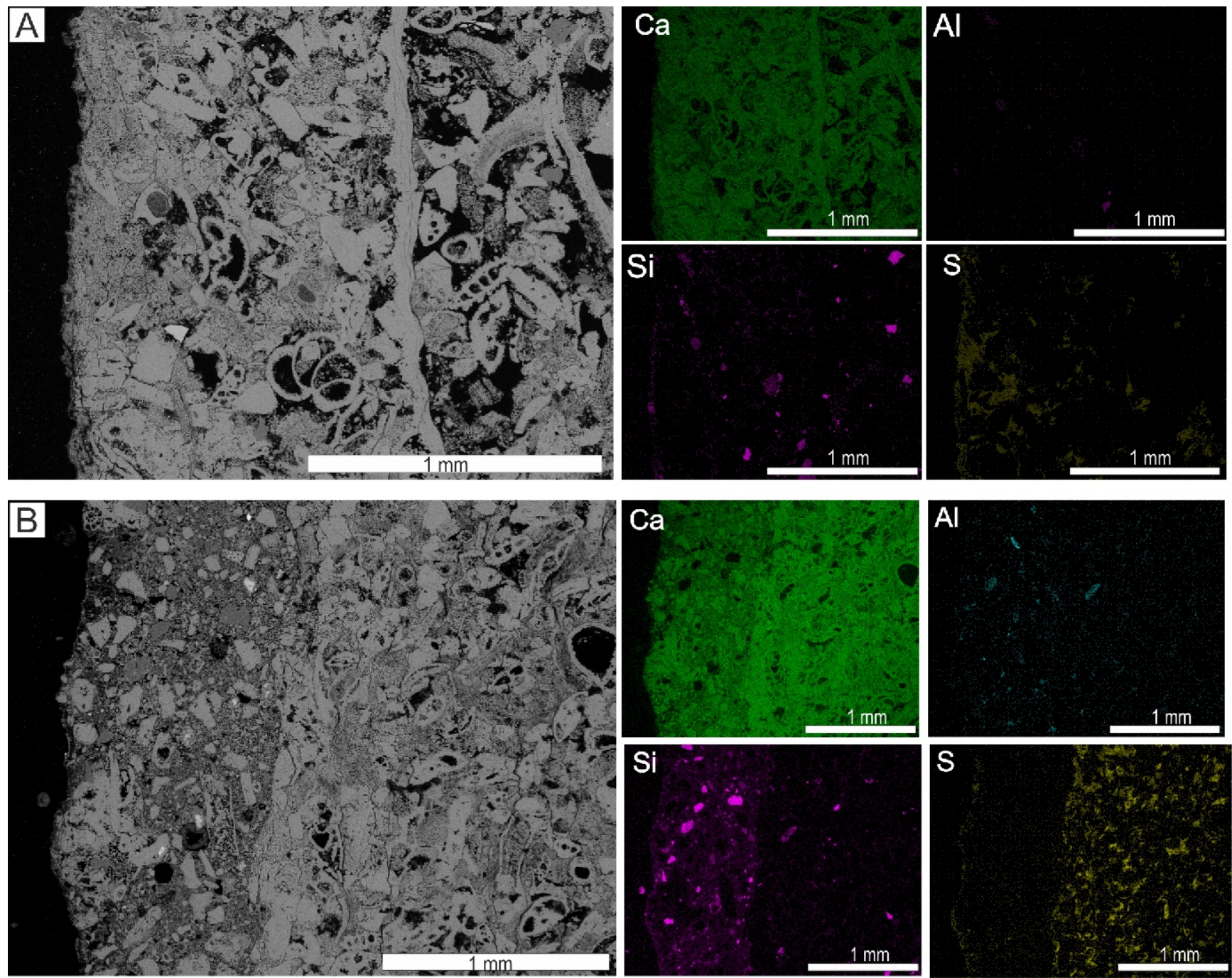

Fig. 3. Distribution of $\mathrm{Ca}, \mathrm{Si}, \mathrm{Al}$ and $\mathrm{S}$ within the cross-section of the crust and the building material below in the samples representing rusticated KD-M-4 (A) and non-rusticated KD-M-4-1 (B) facade blocks made of the Pińczów limestone and covered in places with cement render in the case of KD-M-4-1

For detailed sample code explanations see Figure 1 and Table 1

Pińczów limestone as well. However, they are both covered with a cement render ranging in thickness from a few (KD-M-4-3) to several mm (KD-M-4-2). This outer layer proved to contain fragments of carbonate bioclasts, sharp-edged quartz grains, opaque components, as well as aggregates of high relief, colourless or coloured, mostly isotropic or very slightly anisotropic (very low birefringence), difficult to unequivocal identification (Fig. 2C, D). SEM-EDS analysis allowed identifying in their composition the presence of $\mathrm{Ca}, \mathrm{Si}, \mathrm{Mg}, \mathrm{Al}$ and $\mathrm{O}$, sometimes $\mathrm{Fe}$ as well (Fig. 5). They were apparently formed as a result of technological processes and represent residual cement grains - clinker. The components are cemented with very fine-crystalline mass, presumably carbonate micrite which is also indicated by the elemental composition obtained with the SEM-EDS method. X-ray powder diffractometry (XRPD) of sample KD-M-4-3 revealed only calcite, quartz and gypsum, the latter possibly related to the above-described anthropogenic processes. XRPD analysis of sample KD-M-4-2 allowed determining calcite, portlandite $\mathrm{Ca}(\mathrm{OH})_{2}$, ettringite $\mathrm{Ca}_{6} \mathrm{Al}_{2}\left(\mathrm{SO}_{4}\right)_{3}(\mathrm{OH})_{12} \cdot 26 \mathrm{H}_{2} \mathrm{O}$, quartz, dolomite $\mathrm{CaMg}\left(\mathrm{CO}_{3}\right)_{2}$ and monosulphite $\mathrm{Ca}_{4} \mathrm{Al}_{2} \mathrm{O}_{6} \mathrm{SO}_{3} \cdot 11 \mathrm{H}_{2} \mathrm{O}$ (Fig. 6). These components suggest the presence of either the Roman or ordinary Portland cement (RC or OPC)

Roman cements differ from Portland ones by the phase composition resulting from considerably different (lower) calcination temperatures: $800-1200^{\circ} \mathrm{C}$ and $1400^{\circ} \mathrm{C}$, respectively (Szeląg et al., 2008, 2009; Kozłowski et al., 2010). The following compounds would eventually form in an RC (however, their amounts vary depending on calcination temperatures): wollastonite (monocalcium silicate, $\mathrm{CaO} \cdot \mathrm{SiO}_{2}, \mathrm{CS}$ ), belite (dicalcium silicate, $2 \mathrm{CaO} \cdot \mathrm{SiO}_{2}, \quad \mathrm{C}_{2} \mathrm{~S}$ ), gehlenite (dicalcium aluminosilicate, $2 \mathrm{CaO} \cdot \mathrm{Al}_{2} \mathrm{O}_{3} \cdot \mathrm{SiO}_{2}, \mathrm{C}_{2} \mathrm{AS}$ ), aluminate (tricalcium aluminate, $3 \mathrm{CaO} \cdot \mathrm{Al}_{2} \mathrm{O}_{3}, \mathrm{C}_{3} \mathrm{~A}$ ), and ferrite, also called brownmillerite (tetracalcium aluminoferrite, $4 \mathrm{CaO} \cdot \mathrm{Al}_{2} \mathrm{O}_{3} \cdot \mathrm{Fe}_{2} \mathrm{O}_{3}, \mathrm{C}_{4} \mathrm{AF}$ ). The major compounds present in OPC clinkers are alite (tricalcium silicate, $3 \mathrm{CaO} \cdot \mathrm{SiO}_{2}, \mathrm{C}_{3} \mathrm{~S}$; predominant component, making up $50-70 \%)$, belite $\left(\mathrm{C}_{2} \mathrm{~S}\right.$; which makes up $\left.15-30 \%\right)$, aluminate $\left(C_{3} A\right)$ and ferrite $\left(C_{4} A F\right)$ (Weber et al., 2007). While belite ( $\beta$-belite, $\beta-\mathrm{C}_{2} \mathrm{~S}$ and $\alpha^{\prime}$-belite, $\alpha^{\prime}-\mathrm{C}_{2} \mathrm{~S}$ with the latter being predominant) is the major hydraulic phase in Roman cements, alite $\left(\mathrm{C}_{3} \mathrm{~S}\right)$ is the major phase in ordinary Portland cements. In contrast to the OPC, alite cannot form in the RC because of low cal- 


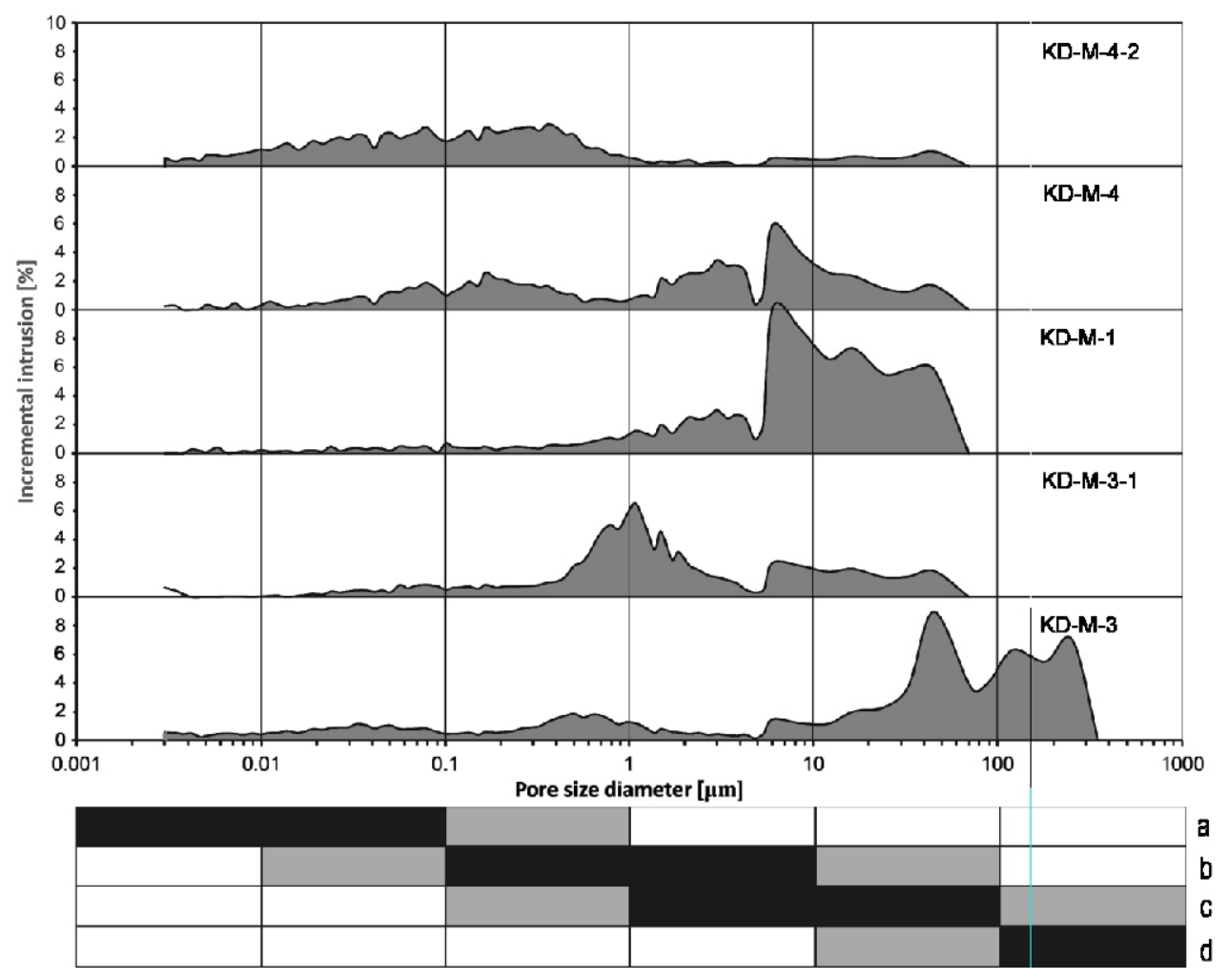

Fig. 4. The pore-size distribution of the building materials (samples KD-M-3, KD-M-3-1, KD-M-1, KD-M-4, KD-M-4-2; for sample code explanations see Fig. 1 and Table 1) compared with some processes: (a) vapour absorption and capillary condensation, (b) salt and ice crystallization, (c) capillary imbibitions and (d) mechanical strength in the pore space of materials; the intensities and ranges of the processes after Benavente (2011)

cination temperatures. After hydration, both belite ( $\alpha$ '-belite is more reactive then $\beta$-belite) and alite form hydrated calcium silicates ( $\mathrm{CSH}$ phases), being the main components of the cements, and portlandite. Calcium carbonates (calcite and vaterite) are products of carbonation of calcium hydroxide (a product of hydration of lime - $\mathrm{CaO}$, formed after calcination of raw material, which reacts with $\mathrm{CO}_{2}$ during hardening of cement, forming $\mathrm{CaCO}_{3}$ ). Ettringite is a primary hydration product in the ordinary Portland cement (reaction between the calcium aluminate and the sulphate from added gypsum), but rapidly dissolves after the sulphate depletion. However, this phase can precipitate when external or internal sources of sulphate are available, e.g. atmospheric $\mathrm{SO}_{2}$ (Gossellin et al., 2012a, b). It was also reported as one of the components of the Roman cement (Adamski et al., 2009). Monosulphite is also a product of cement hydration (in cementitious systems, sulphite ions are often observed when sulphuric sources are available; Łagosz and Małolepszy, 2003; Suh et al., 2019). Unreacted and unhydrated components of Roman cements (in good quality cements present only in very small quantities $)$ - calcium silicates: $\beta$-belite $\left(\beta-C_{2} S\right.$; as less reactive then $\alpha$ '-belite), gehlenite $\left(C_{2} A S\right)$ and wollastonite $(C S)$ can be labelled as Roman cement fingerprint phases (Adamski et al., 2009; Kozłowski et al., 2010). These phases can survive in unreacted grains of Roman cements or encapsulated in mortars because of their low hydration rates, like relics of alite, which are characteristic of OPC and absent in RC (Pintér et al., 2014; Pintér and Gosselin, 2018). Although XRPD analyses did not reveal their presence in the samples analysed, the occurrence of these phases could be also supported through scanning electron microscopy (SEM-EDS), by which they can be visible in the binder-related grains. Though detailed quantitative analyses are beyond the scope of this research, and will be the topic of a separate study, preliminary observations of the samples in this respect reveal relics of the original cement in both of the samples (Fig. 5). Their characteristics, based on crosschecked results obtained by OM and SEM-EDS analyses, point out the use of the Portland cement. In a microscopic image, hydrated binder appears as very fine groundmass encapsulating significant amounts of remnants of the original cement clinker, identified as alite and belite. $\mathrm{C}_{3} \mathrm{~S}$ exhibits mainly subhedral, rounded or distorted crystals, with less distinct rims and frequent coalescent grains, up to $100 \mu \mathrm{m}$ in size. Most of the $\mathrm{C}_{3} S$ grains are corroded and surrounded by secondary $\mathrm{C}_{2} \mathrm{~S}$ crystals and/or partly carbonated hydration rims. Belite forms rounded crystals, usually several $\mu \mathrm{m}$ in size, but frequently larger clusters, up to $100 \mu \mathrm{m}$. In some cases, SEM analysis reveals characteristic parallel lamellae. Apart from typical, round crystals, some atypical were observed as well. They are elongated, often showing cleavage. Along with the alite and belite phases, interstitial groundmass, composed of aluminate $\left(C_{3} A\right)$ and ferrite $\left(C_{4} A F\right)$, occurs within the clusters.

Sample KD-M-4-2 is characterized by a high open porosity of $31.54 \%$ and a bulk density of $1.77 \mathrm{~g} / \mathrm{cm}^{3}$. Its pore-size distribution reveals the dominance of pores in two ranges: $1.0-0.1 \mu \mathrm{m}$, that makes up $45.25 \%$, and $0.1-0.003 \mu \mathrm{m}$ (46.33\%). Larger pores of $10.0-1.0 \mu \mathrm{m}$ make up $4.9 \%$, and the pores of $70-10 \mu \mathrm{m}-3.46 \%$ (Fig. 4). The average pore diameter is $0.03 \mu \mathrm{m}$, and the total pore area is $20.31 \mathrm{~m}^{2} / \mathrm{g}$. The quite high hysteresis effect $(45 \%)$ and very low threshold diameter $(0.5 \mu \mathrm{m})$ suggest that the internal movement of solutions 

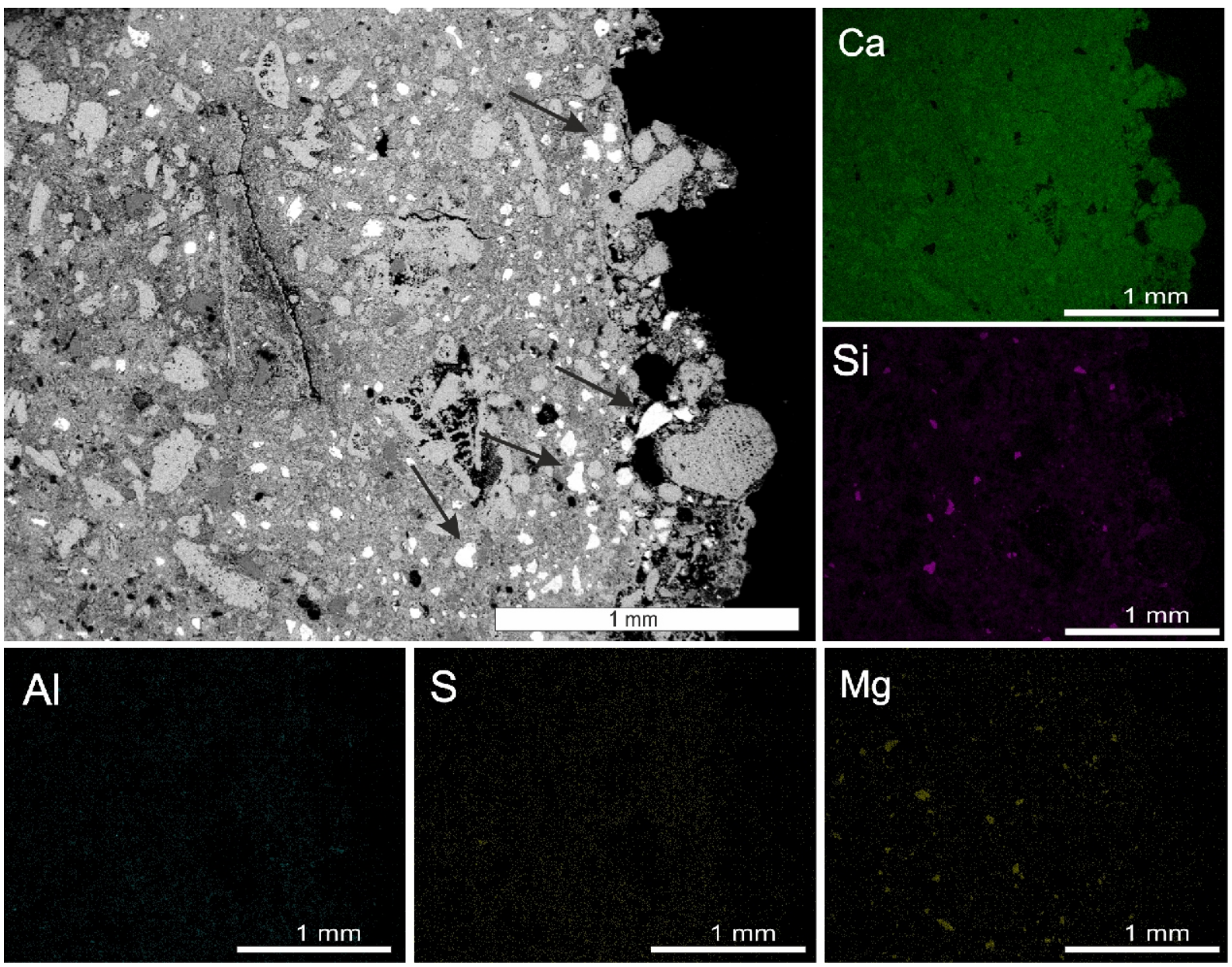

Fig. 5. Distribution of $\mathrm{Ca}, \mathrm{Si}, \mathrm{Al}, \mathrm{S}$ and $\mathrm{Mg}$ within the cross-section of a sample representing cement-rendered blocks $\mathrm{KD}-\mathrm{M}-4-2$ Cement clinker clusters are marked with arrows; for sample code explanations see Figure 1 and Table 1

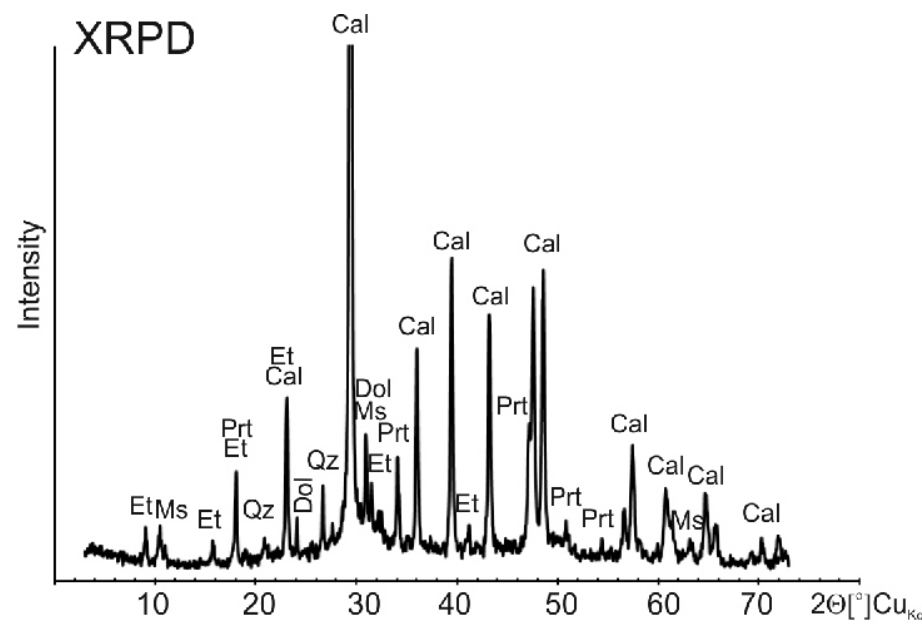

Fig. 6. Representative X-ray pattern of the cement KD-M-4-2

Cal - calcite, Dol - dolomite, Et - ettringite, Ms - monosulphite, Prt portlandite, Qz - quartz; for sample code explanations see Figure 1 and Table 1 

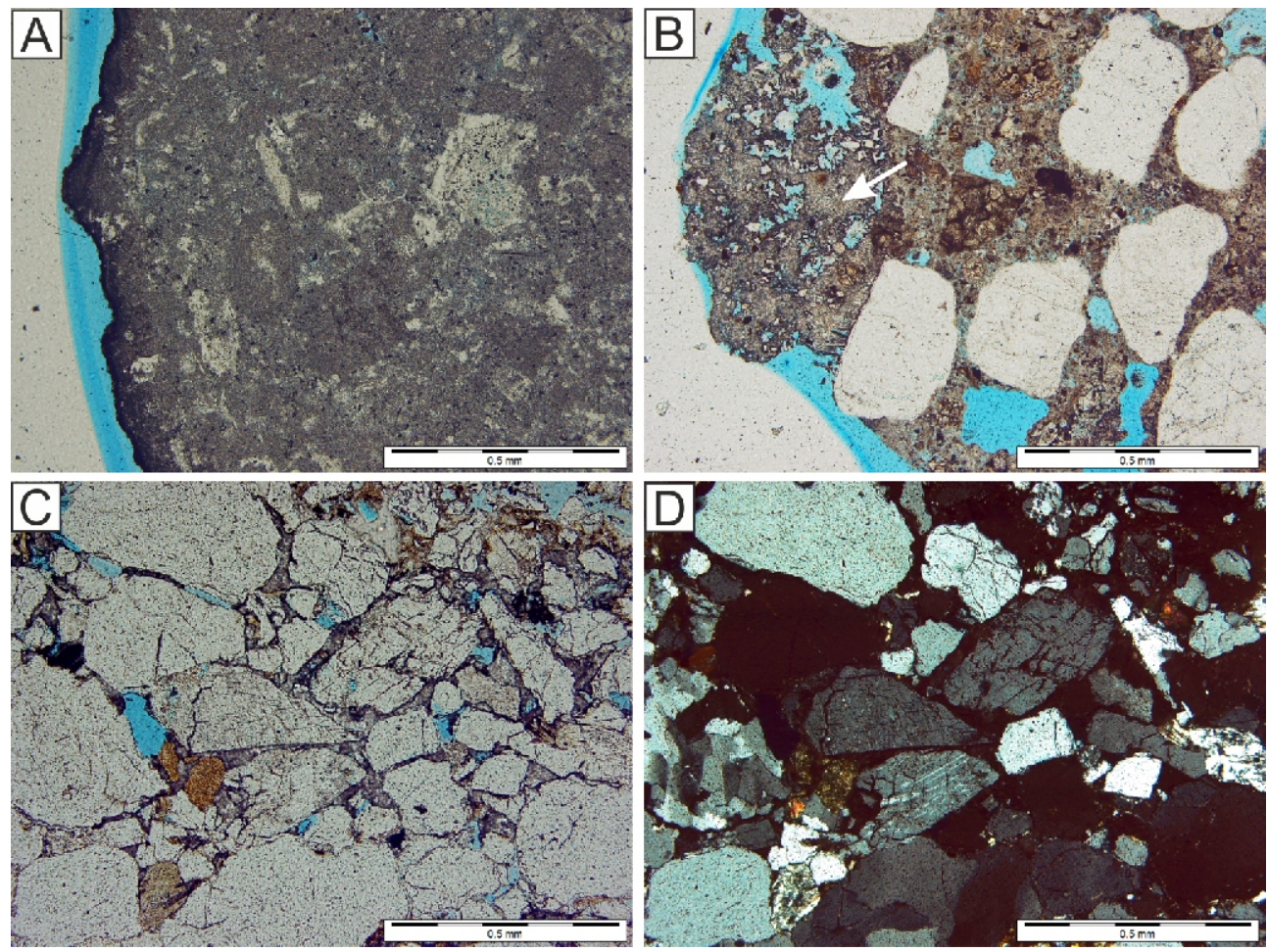

Fig. 7. Microphotographs of the samples taken from the exposed foundations: Jurassic limestone KD-M-3-1 (A), cement mortar KD-M-3 (B, plane-polarized light) and sandstone KD-M-1 (C, D, one polar and crossed polars, respectively)

The arrow indicates the outer layer - crust of the building materials; for detailed sample code explanations see Figure 1 and Table 1

through the stone is very difficult and inferior. The permeability is very low $0.075 \mathrm{mD}$. The pore distribution is unimodal and heterogeneous with the pores in the range of $1.0-0.003 \mu \mathrm{m}$.

SUBWALL OF THE MYSZKOWSKIS CHAPEL

The exposed foundations are made of irregular pieces of limestones and sandstones, bound with and partly replaced by cement mortar (Fig. 1C).

Limestone blocks (KD-M-3-1) are bright organogenic micritic limestones with relatively scarce bioclasts, mostly sparite shells, up to $4-5 \mathrm{~mm}$ in cross-sections. The fauna (brachiopods, bivalves, gastropods etc.) points out for local Upper Jurassic limestones (Gradziński, 1972; Rajchel, 2004; Fig. 7A). The samples analysed also exhibited fragmented segments of an external alteration layer ( $10 \mu$ m thick) with abundant calcium sulphates and particles of atmospheric dust (Fig. 8). Moreover, up to a depth of $\sim 50 \mu \mathrm{m}$ from the surface the limestone proved to be enriched in $\mathrm{Si}$ and $\mathrm{O}$, more superficially (up to $\sim 10 \mu \mathrm{m}$ in depth) in Al as well (Fig. 8). The origin of these elements is uncertain; they could be connected with earlier conservation works of the subwall, e.g. consolidation using waterglass, fluosilicates, silica sol, and silicate esters (Domasłowski, 1993; Snethlage and Sterflinger, 2011). Higher concentrations of the same elements ( $\mathrm{Si}, \mathrm{Al}$ and $\mathrm{O}$ ) were also noted in the superficial layer (up to $\sim 500 \mu \mathrm{m}$ in depth from the surface) of the sandstone blocks, in which they apparently formed amorphic cement of the framework grains (Fig. 9A). At the surface of the Jurassic limestone, a thin monomineral layer of barium sulphate (barite $\mathrm{BaSO}_{4}$ ) was observed as well (Fig. 8). Barium could be deliberately introduced into the stony blocks at the restoration procedures, in which barium chloride $\left(\mathrm{BaCl}_{2}\right)$ or barium hydroxide $\left(\mathrm{Ba}(\mathrm{OH})_{2}\right)$ are the chemicals used for removal of del- eterious salts (e.g., $\mathrm{Na}_{2} \mathrm{SO}_{4}$ ) and for stone consolidation (Domasłowski, 1993; Snethlage and Sterflinger, 2011). On the other hand, the limestone itself could also be a possible source of barium, as $\mathrm{Ba}$ (and other trace elements, e.g., Sr) concentrates in aragonite $\left(\mathrm{CaCO}_{3}\right.$ polymorph) skeletal parts of marine invertebrates. With time, aragonite grades into calcite, in which $\mathrm{Ba}$ (also $\mathrm{Sr}$ ) commonly exhibits lower concentrations (Boggs, 2010).

The stone analysed is characterized by a relatively low open porosity of $15.76 \%$ and a bulk density of $2.18 \mathrm{~g} / \mathrm{cm}^{3}$. Its pore-size distribution indicates the dominance of pores in two ranges: $10.0-1.0 \mu \mathrm{m}$, that makes up $41.24 \%$ and $1.0-0.1 \mu \mathrm{m}$ (40.94\%). The pores of $70-10 \mu \mathrm{m}$ make up $8.56 \%$ and the pores of $0.1-0.003 \mu \mathrm{m}-9.21 \%$ (Fig. 4). The average pore diameter (calculated as a weighted average, with the weight determining the number of pores, and not the percentage of the pore space) is $0.14 \mu \mathrm{m}$, and the total pore area is $2.02 \mathrm{~m}^{2} / \mathrm{g}$. The internal movement of solutions through the stone is very difficult and inefficient (high hysteresis effect $-47 \%$ and low threshold diameter $-4 \mu \mathrm{m}$ ), and the permeability is $0.67 \mathrm{mD}$. The pore distribution is unimodal, with the dominance of pores in the range of $5.0-0.4 \mu \mathrm{m}$.

Sandstone blocks (sample KD-M-1) are grey-brownish, darker on exposed surfaces, and fine-grained. Quartz grains, up to $0.5 \mathrm{~mm}$, are weakly rounded or even sharp-edged. Accessory components are K-feldspars, plagioclases, micas, opaque phases and dark-grey rock fragments (Fig. 7C, D). Such a composition and abundant clay matrix with dispersed glauconite aggregates are indicative of arkose wacke that could represent the Lower Istebnian Sandstones from the neighbouring Carpathians (Ślączka and Kamiński, 1998; Bromowicz et al., 2001; Rajchel, 2004; Rembiś and Smoleńska, 2010). 

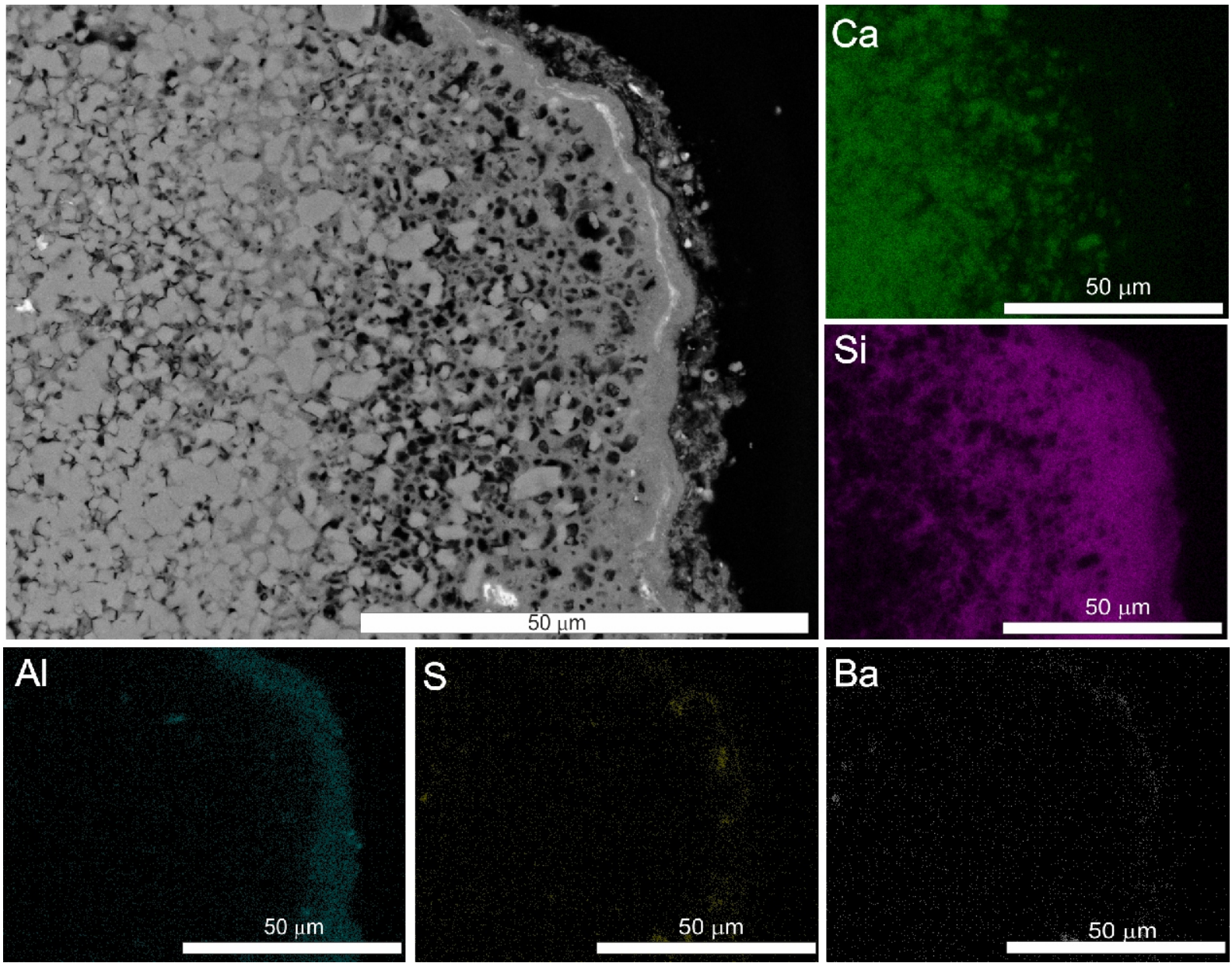

Fig. 8. Distribution of $\mathrm{Ca}, \mathrm{Si}, \mathrm{Al}, \mathrm{S}$ and $\mathrm{Ba}$ within the cross section of the Jurassic limestone block of sample KD-M-3-1

For detailed sample code explanations see Figure 1 and Table 1

XRPD analyses confirmed the presence of quartz, K-feldspars and plagioclases, mica and illite group minerals, kaolinite and gypsum. The last is concentrated on the surface and in intragrain spaces in the form of dispersed euhedral crystals. In the sandstone superficial layer (up to $\sim 500 \mu \mathrm{m}$ from the surface), amorphic "cement" (mainly consisting of Si and O) was found between the framework grains (Fig. 9A), where it was presumably deliberately introduced as a conservation material. At freshly broken sandstone surfaces, characteristic exfoliating flakes of the same composition were detected, apparently relics of a consolidating material.

Based on of mercury-intrusion porosimetry measurements, the sample reveals relatively low open porosity of $15.30 \%$ and a bulk density of $2.06 \mathrm{~g} / \mathrm{cm}^{3}$. Its pore-size distribution shows the dominance of pores in the ranges of 10.0-1.0 $\mu \mathrm{m}$ and $70-10 \mu \mathrm{m}$ that make up 49.17 and $31.08 \%$, respectively. The pores of $1.0-0.1 \mu \mathrm{m}$ make $12.86 \%$ and $0.1-0.003 \mu \mathrm{m} 6.88 \%$ (Fig. 4). The average pore diameter (calculated as a weighted average, with the weight determining the number of pores, and not the percentage of the pore space) is $0.21 \mu \mathrm{m}$, and the total pore area is $1.38 \mathrm{~m}^{2} / \mathrm{g}$. The very low hysteresis effect and high threshold diameter $(70 \mu \mathrm{m})$ suggest that the internal movement of solutions through the stone is easy. The permeability is $7.09 \mathrm{mD}$. The pore distribution is unimodal, with the dominance of pores in the range of 70-1.0 $\mu \mathrm{m}$.

Cement mortar (sample KD-M-3) in a microscopic image (OM) displays the presence of well-rounded quartz grains, rock fragments, and feldspars (both potassic and plagioclases; Fig. 7B). These grains are cemented with very fine-grained mass containing $\mathrm{Ca}, \mathrm{Si}, \mathrm{Al}$ and $\mathrm{O}$ (Fig. 9B), in which larger yellowish aggregates with high relief and low interference colours or even optically isotropic were observed as well (Fig. 7B). Their chemical composition is variable; except aggregates mostly composed of $\mathrm{Si}, \mathrm{Ca}, \mathrm{O}$, particles containing also $\mathrm{Al}, \mathrm{Mg}, \mathrm{Fe}, \mathrm{C}$ and $S$ were noted as well (Fig. 9B). They represent residual unhydrated clinker grains of OPC. Preliminary analyses allow distinguishing among them clusters with alite $\mathrm{C}_{3} \mathrm{~S}$, belite $\mathrm{C}_{2} \mathrm{~S}$, aluminate $C_{3} A$ and ferrite $C_{4} A F$, all below $100 \mu m$ in size. Typical belite crystals are rounded, several $\mu \mathrm{m}$ in size, most of them exhibit one set of parallel or two sets of intersecting lamellae. Alite crystals are angular, subhedral in shapes and $10-50 \mu \mathrm{m}$ in size; however, $\mathrm{C}_{2} \mathrm{~S}$ is more abundant than $\mathrm{C}_{3} \mathrm{~S}$. Aluminate $\left(C_{3} A\right)$ and ferrite $\left(C_{4} A F\right)$ occur as interstitial phases within the clusters. Relics of charcoal used as a fuel for cement burning were detected as well.

Phase composition (XRPD) of the cement mortar samples reveals only quartz, calcite, feldspars and gypsum. In places, the surface of the samples is coated with a discontinuous layer with colourless, tiny, needle-shaped, almost isotropic components, opaque grains, and sharp-edged iron oxides, apparently formed due to exposition to polluted atmosphere. Main components of that crust layer are calcium sulphates (gypsum, detected by XRPD analyses), observed also more deeply within the sample (Figs. 7B and 9B). 

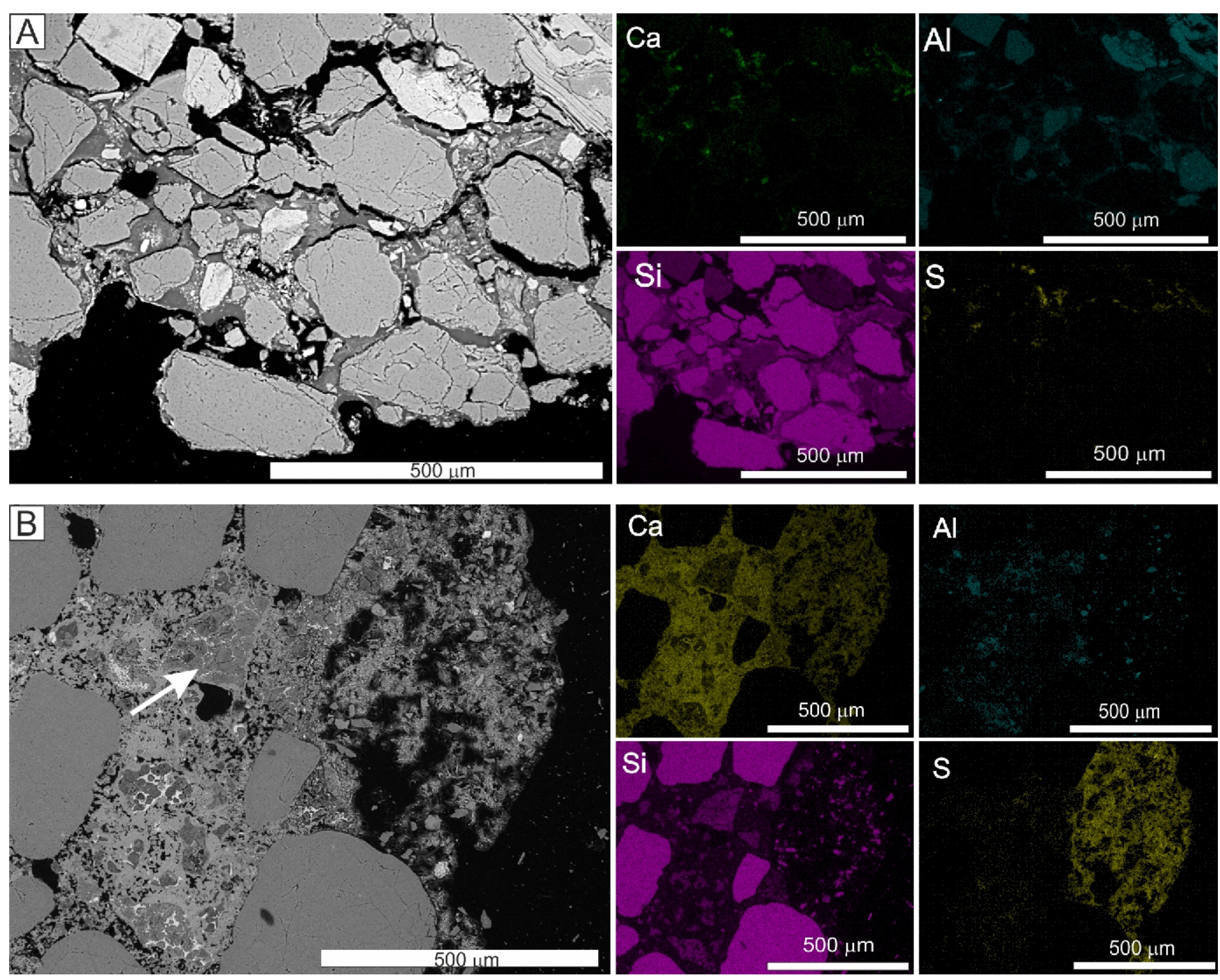

Fig. 9. Distribution of $\mathrm{Ca}, \mathrm{Si}, \mathrm{Al}$ and $\mathrm{S}$ within the cross section of subwall samples: sandstone block KD-M-1 (A) and cement mortar KD-M-3 (B)

For detailed sample code explanations see Figure 1 and Table 1; in B cement clinker clusters are marked with an arrow

The sample is characterized by an open porosity of $18.33 \%$ and a bulk density of $2.08 \mathrm{~g} / \mathrm{cm}^{3}$. Its pore-size distribution indicates the pores in the following ranges: $350-10 \mu \mathrm{m}$ that makes up $44.8 \%, 1.0-0.1 \mu \mathrm{m}(22.9 \%)$, and $0.1-0.003 \mu \mathrm{m}(21.5 \%)$ The pores of $10.0-1.0 \mu \mathrm{m}$ make up $10.8 \%$ (Fig. 4). The average pore diameter (calculated as a weighted average, with the weight determining the number of pores, and not the percentage of the pore space) is $0.06 \mu \mathrm{m}$, and the total pore area is $5.69 \mathrm{~m}^{2} / \mathrm{g}$. The quite low hysteresis effect $(28 \%)$ and threshold diameter $(50 \mu \mathrm{m})$ suggest that the internal movement of solutions through the material is easy. The permeability is $8.96 \mathrm{mD}$.

\section{SECONDARY MINERALS}

Microscopic analysis (OM) revealed that all the materials analysed, except cement renders (KD-M-4-2), were covered with thin surface coatings, in which gypsum was identified in some samples. In most of the samples, submicroscopic sizes of the components did not allow for unequivocal identification; however, the XRPD analyses pointed out the presence of gypsum as well.
The SEM-EDS analyses provided more detailed morphological and chemical (major and minor elements) characteristics of secondary salts of the crusts. However, they did not give any clue as to their hydration state. To corroborate the authors' suppositions based on the SEM-EDS results, the identifications had to be crosschecked using the XRPD and Raman microspectroscopy results (Marszałek, 2016). These methods have been also used to analyze salt efflorescences found on the border between the limestone blocks and the cement mortar in some places of the foundations of the Myszkowskis Chapel.

\section{OUTER SURFACE OF THE MATERIALS}

\section{GYPSUM}

Most distinct gypsum concentrations forming outer layers (up to several hundred $\mu \mathrm{m}$ ) were observed in elements made of the Pińczów limestone (KD-M-4, KD-M-4-1, KD-M-4-3) and the cement mortar sample (KD-M-3; Figs. 2A, B, D and 7B). This mineral occurs as small plate-like crystals, up to several tens of $\mu \mathrm{m}$ in length. On the surface, it sometimes accumulates in the form of cascades (KD-M-4; Fig. 10A) or rosettes (KD-M-3). 

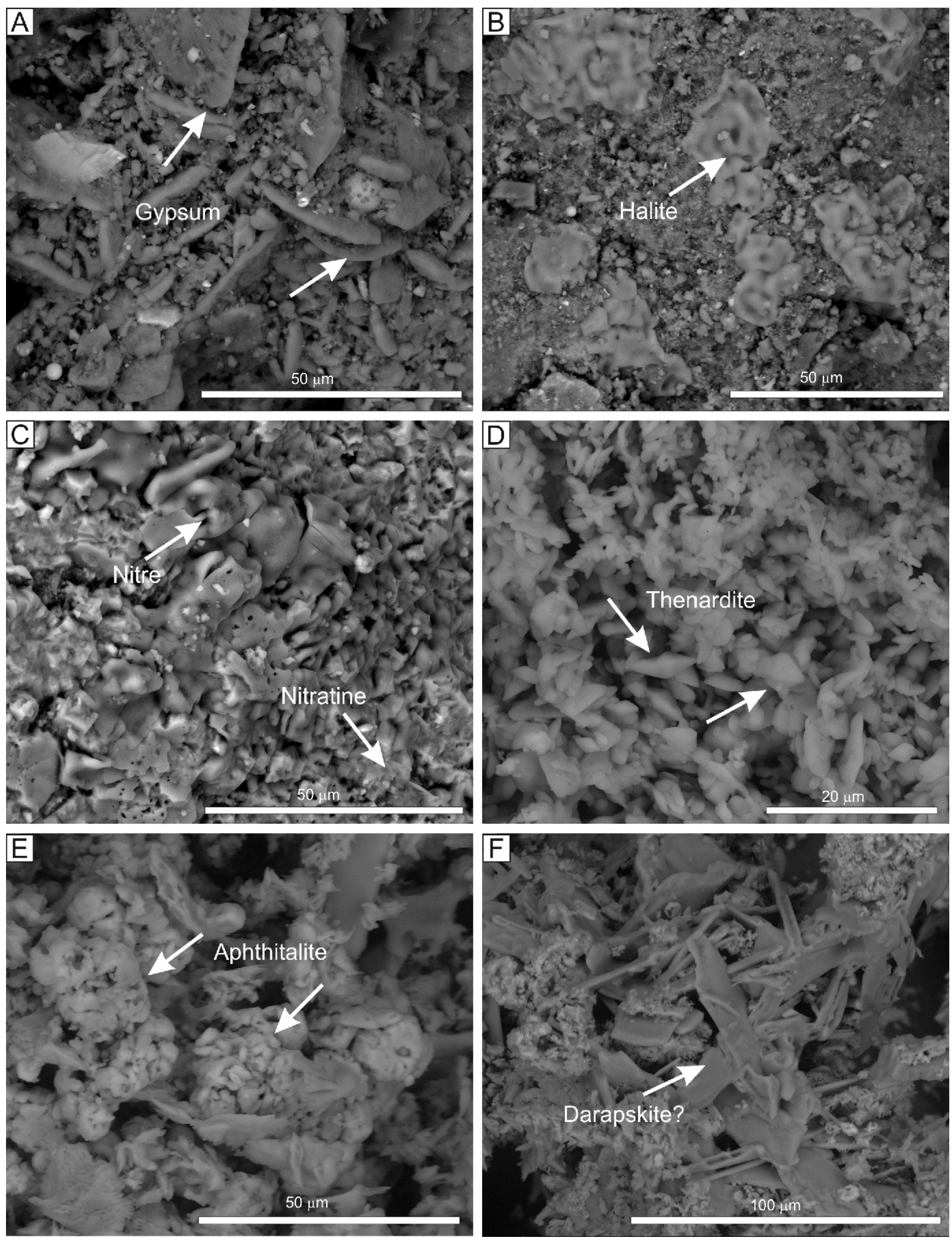

Fig. 10. BEl images (A-F) of the secondary salts from the outer layer crust (A-C - samples of limestones KD-M-4, KD-M-4-1 and KD-M-3-1, respectively) and efflorescences (D-F - sample KD-M-3-2s on the border between the limestone blocks and the cement replacements) 


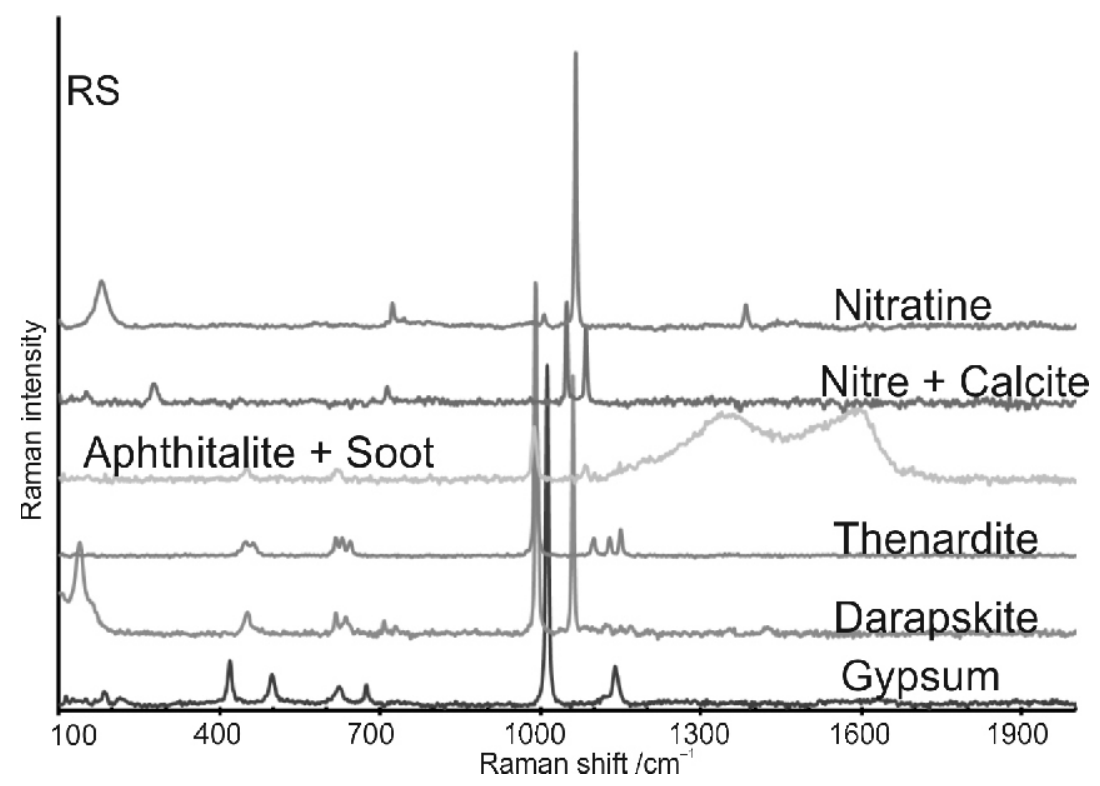

Fig. 11. Representative characteristic Raman spectra of the secondary salts from the outer layer crust and efflorescences

For the characteristic Raman bands used for salt identification see Table 2; the broad Raman bands at $\sim 1600$ and $\sim 1300 \mathrm{~cm}$ ( $G$ and $D$ peaks, respectively) are connected with carbonaceous matter, probably soot (Sadezky et al., 2005)

Its presence was also detected inside the samples analysed. For example, in the Pińczów limestone, gypsum replaced calcite micrite or crystallized in sandstone intra-grain spaces and pores (e.g., KD-M-1). Surface distribution patterns of sulphur are demonstrated on maps, in cross-sections perpendicular to the materials analysed in SEM-EDS (Figs. 3, 8 and 9). In most of the samples, the pore-size distribution distinctly points out susceptibility to salt crystallization in pores of the materials investigated (Fig. 4). The presence of gypsum was confirmed by Raman spectroscopy. The main Raman band at $1010 \mathrm{~cm}^{-1}$ $\left(v_{1}\right)$, minor bands at 416 and $492 \mathrm{~cm}^{-1}$, as well as the 621 and $672 \mathrm{~cm}^{-1}\left(v_{2}\right.$ and $\left.v_{4}\right)$ and $1136 \mathrm{~cm}^{-1}\left(v_{3}\right)$ vibrations of $\mathrm{SO}_{4}^{2-}$ (Buzgar et al., 2009; Prieto-Taboada et al., 2014) prove the presence of $\mathrm{CaSO}_{4} \cdot 2 \mathrm{H}_{2} \mathrm{O}$ (Fig. 11 and Table 2).

HALITE

Halite $\mathrm{NaCl}$ was observed in samples of subwall (sandstone blocks KD-M-1) and fasade elements (Pińczów limestones KD-M-4-1 and KD-M-4-3). It forms irregular crusts and cubic crystals with distinct traces of dissolution (Fig. 10B). Its presence was determined only with the SEM-EDS analysis.

NITRE AND NITRATINE

Nitrate salts - nitre $\mathrm{KNO}_{3}$ and nitratine $\mathrm{NaNO}_{3}$ - have been detected based on SEM-EDS analyses on the surface of the Jurassic limestone (KD-M-3-1) near the efflorescences. Nitratine was also found on the rusticated wall blocks (KD-M-4). Crystals of these salts exhibit anhedral shapes with signs of dissolution (Fig. 10C). The presence of $\mathrm{KNO}_{3}$ has also been inferred from its main Raman band at $1047 \mathrm{~cm}^{-1}$. Raman spectra revealed also the presence of $\mathrm{NaNO}_{3}$, based on its main band at $1064 \mathrm{~cm}^{-1}$ (Fig. 11 and Table 2).

\section{EFFLORESCENCES}

The XRPD analyses allowed identifying sodium and potassium sulphates: thenardite $\mathrm{Na}_{2} \mathrm{SO}_{4}$ and aphthitalite (glaserite) $(\mathrm{K}, \mathrm{Na})_{3} \mathrm{Na}\left(\mathrm{SO}_{4}\right)_{2}$, and sulphate-nitrate salt - darapskite

Characteristic Raman bands used for identification of soluble salts

\begin{tabular}{|c|c|c|}
\hline Compound & Formula & Raman shift $\left[\mathrm{cm}^{-1}\right]$ \\
\hline Aphthitalite & $(\mathrm{KNa})_{3} \mathrm{Na}\left(\mathrm{SO}_{4}\right)_{2}$ & $449 v_{2}, 986 v_{1}, 1082 v_{3}, 1203$ \\
\hline Darapskite & $\mathrm{Na}_{3}\left(\mathrm{SO}_{4}\right)\left(\mathrm{NO}_{3}\right) \cdot \mathrm{H}_{2} \mathrm{O}$ & $\begin{array}{c}452 v_{2} \mathrm{SO}_{4}^{2-}, 617 \text { and } 640 v_{4} \mathrm{SO}_{4}^{2-}, 706 v_{4} \mathrm{NO}_{3}^{-}, 728 v_{4} \mathrm{SO}_{4}^{2-}, 992-989 v_{1} \mathrm{SO}_{4}^{2-}, 1060 v_{1} \mathrm{NO}_{3}^{-}, \\
1083 \text { and } 1123 v_{3} \mathrm{SO}_{4}^{2-}, 1353 v_{3} \mathrm{NO}_{3}^{-}\end{array}$ \\
\hline Gypsum & $\mathrm{CaSO}_{4} \cdot 2 \mathrm{H}_{2} \mathrm{O}$ & $416 v_{2}, 492 v_{2}, 621 v_{4}, 672 v_{4}, 1010 v_{1}, 1136 v_{3}$ \\
\hline Nitre & $\mathrm{KNO}_{3}$ & $1047 v_{1}$ \\
\hline Nitratine & $\mathrm{NaNO}_{3}$ & $1064 v_{1}$ \\
\hline Thenardite & $\mathrm{Na}_{2} \mathrm{SO}_{4}$ & $449 v_{2}, 460 v_{2}, 617 v_{4}, 629 v_{4}, 643 v_{4}, 990 v_{1}, 1099 v_{3}, 1128 v_{3}, 1149 v_{3}$ \\
\hline
\end{tabular}




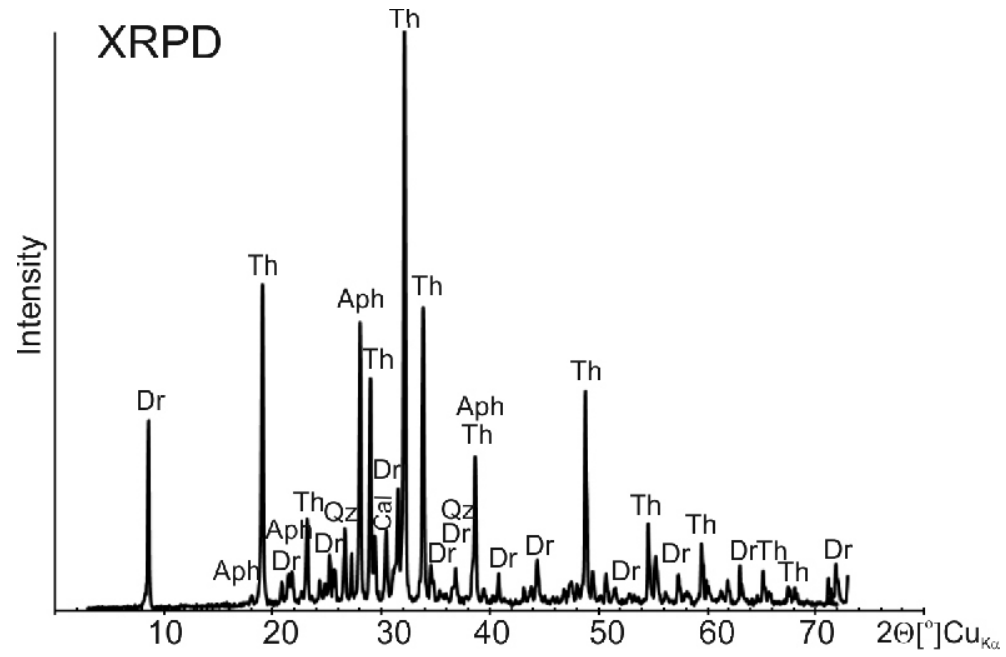

Fig. 12. Representative X-ray pattern of the efflorescences (KD-M-3-2s) sampled from the border between the subwall limestone blocks and cement mortar

Aph - aphthitalite, Cal - calcite, Dr - darapskite, Th - thenardite, Qz - quartz

$\mathrm{Na}_{3}\left(\mathrm{SO}_{4}\right)\left(\mathrm{NO}_{3}\right) \cdot \mathrm{H}_{2} \mathrm{O}$. The remaining components include calcite and quartz, mostly related to the underlying primary material (Fig. 12).

SINGLE SALTS - THENARDITE

Characteristic euhedral (bipyramidal) crystals of thenardite consisting of $\mathrm{Na}, \mathrm{S}$ and $\mathrm{O}$ are often observed (Fig. 10D). Their length does not exceed $20 \mu \mathrm{m}$. This mineral has been identified based on its Raman spectrum (Fig. 11 and Table 2): main band at $990 \mathrm{~cm}^{-1}\left(v_{1} \mathrm{SO}_{4}^{2-}\right)$, the characteristic set of bands at 449 , $460 \mathrm{~cm}^{-1}\left(v_{2} \mathrm{SO}_{4}^{2-}\right)$, and 617,629 and $643 \mathrm{~cm}^{-1}\left(v_{4} \mathrm{SO}_{4}^{2-}\right)$, and other bands at 1099, 1128 and $1149 \mathrm{~cm}^{-1}\left(\mathrm{v}_{3} \mathrm{SO}_{4}^{2-}\right)$ (Prieto-Taboada et al., 2019). On the other hand, mirabilite $\mathrm{Na}_{2} \mathrm{SO}_{4} \cdot 10 \mathrm{H}_{2} \mathrm{O}$ could also occur. Mirabilite prevails at $\mathrm{RH}>76.4 \%$, but with increasing temperature and decreasing humidity, it grades into thenardite (Hamilton and Menzies, 2010; De Clercq et al., 2013). However, distinguishing mirabilite from thenardite in Raman spectroscopy could be ambiguous because of close positions of their main Raman bands (Hamilton and Menzies, 2010; Prieto-Taboada et al., 2019). Such salts, which exist in anhydrous forms or can crystallize as various hydrates, are particularly damaging. The volumetric changes of reversible dissolving/recrystallizing processes in case of anhydrous thenardite - decahydrous mirabilite - reach even $314 \%$, and the stone damage results just from the crystallization pressure generated in their course (Rodriguez-Navarro and Doehme, 1999).

DOUBLE SALTS - APHTHITALITE AND DARAPSKITE

Both aphthitalite $(\mathrm{K}, \mathrm{Na})_{3} \mathrm{Na}\left(\mathrm{SO}_{4}\right)_{2}$ and darapskite $\mathrm{Na}_{3}\left(\mathrm{SO}_{4}\right)\left(\mathrm{NO}_{3}\right) \cdot \mathrm{H}_{2} \mathrm{O}$ are incongruently soluble double salts, that is, under equilibrium conditions, these compounds do not crystallize from a solution of their own stoichiometric compositions (Linnow et al., 2013; Lindström et al., 2015). Such salts display complex crystallization behaviour and may be high damaging for the stones (Linnow et al., 2013; Lingström et al., 2015).
Aphthitalite can crystallize from mixtures containing solutions of sodium sulphate $\left(\mathrm{Na}_{2} \mathrm{SO}_{4}\right)$ and potassium sulphate $\left(\mathrm{K}_{2} \mathrm{SO}_{4}\right)$. According to solubility data, this mineral should precipitate as the first upon evaporation of an equimolar mixed solution of these sulphates (Silcock, 1979).

Darapskite is a mineral of the $\mathrm{Na}_{2} \mathrm{SO}_{4}-\mathrm{NaNO}_{3}-\mathrm{H}_{2} \mathrm{O}$ system. This mineral is stable between 13.5 and $74^{\circ} \mathrm{C}$ and can never occur together with nitratine and thenardite/mirabilite, because the fields of the two latter are separated by the darapskite field (Holtkamp and Hijnen, 1991; Puşcaş et al., 2010). According to the solubility diagram of the $\mathrm{Na}_{2} \mathrm{SO}_{4}-\mathrm{NaNO}_{3}-\mathrm{H}_{2} \mathrm{O}$ system at $20^{\circ} \mathrm{C}$ (Linnow et al., 2013), as water evaporates, the concentration of these two salts increases, first reaching saturation with mirabilite. The remaining solution becomes enriched in nitrate, and then also becomes saturated with darapskite. In the equilibrium conditions, mirabilite will re-dissolve and darapskite will crystallize instead. However, in porous materials, the re-dissolution of mirabilite may not occur, as the evaporation front moves into the interior and the precipitated mirabilite will be separated from the solution. The latter will then first precipitate darapskite, and ultimately nitratine.

The salts found in the efflorescences analysed suggest a more complex system of solutions containing $\mathrm{K}_{2} \mathrm{SO}_{4}-\mathrm{Na}_{2} \mathrm{SO}_{4}-$ $\mathrm{NaNO}_{3}-\mathrm{H}_{2} \mathrm{O}$.

Anhedral, often isometric crystals and irregular aggregates, revealing the presence of $\mathrm{Na}, \mathrm{K}, \mathrm{S}$ and $\mathrm{O}$ in EDS analyses, have been identified as aphthitalite $(\mathrm{K}, \mathrm{Na})_{3} \mathrm{Na}\left(\mathrm{SO}_{4}\right)_{2}$ (Fig. 10E). Sodium and potassium sulphate $(\mathrm{K}, \mathrm{Na})_{3} \mathrm{Na}\left(\mathrm{SO}_{4}\right)_{2}$ and anhydrous sodium sulphate $\left(\mathrm{Na}_{2} \mathrm{SO}_{4}\right)$ have very similar Raman spectra; however, the presence of a band at $\sim 1202 \mathrm{~cm}^{-1}$ and the lack of band at $465 \mathrm{~cm}^{-1}$ (in comparison with thenardite) can be the fingerprint of aphthitalite (Prieto-Taboada et al., 2019). The Raman spectra exhibiting a strong band at $986 \mathrm{~cm}^{-1}$ assigned to the $v_{1}$ symmetric stretching mode of the sulphate group and the bands at $449\left(v_{2}\right), 1082\left(v_{3}\right)$ and $1203 \mathrm{~cm}^{-1}$ confirm the presence of aphthitalite (Fig. 11 and Table 2). These Raman bands correspond also to the data given by Hansteen and Burke (1994). 
Euhedral, platy crystals of various length up to several tens of $\mu \mathrm{m}$, sometimes fan-shaped, consisting of $\mathrm{Na}, \mathrm{S}$ and $\mathrm{O}$, have been identified as darapskite $\mathrm{Na}_{3}\left(\mathrm{SO}_{4}\right)\left(\mathrm{NO}_{3}\right) \cdot \mathrm{H}_{2} \mathrm{O}$ (Fig. 10F). The Raman spectra of darapskite exhibited strong bands at $1060 \mathrm{~cm}^{-1}$ and $992-989 \mathrm{~cm}^{-1}$ of $v_{1} \mathrm{NO}_{3}^{-}$and $\mathrm{v}_{1} \mathrm{SO}_{4}^{2-}$, respectively (Fig. 11 and Table 2). The bands at 452 can be assigned to $v_{2} \mathrm{SO}_{4}^{2-}, 728$ and $706 \mathrm{~cm}^{-1}$ to $v_{4} \mathrm{SO}_{4}^{2-}$ and $v_{4} \mathrm{NO}_{3}^{-}$accordingly, and $640,617 \mathrm{~cm}^{-1}$ to $\mathrm{v}_{4} \mathrm{SO}_{4}^{2-}$. Weak signals at 1123 and $1083 \mathrm{~cm}^{-1}$ are connected with $v_{3} \mathrm{SO}_{4}^{2-}$, and $1353 \mathrm{~cm}^{-1}$ with $v_{3}$ $\mathrm{NO}_{3}^{-}$(Jentzsch et al., 2012).

\section{ORIGIN OF IONS FOR CRYSTALLIZING PECULIAR SALTS}

The ions for precipitated salts can originate from both anthropogenic and natural sources. The most important external anthropogenic ones include: air pollution - wet and dry airborne deposition that provides mainly sulphate and nitrate anions, as well as road de-icing salts $\left(\mathrm{NaCl}\right.$ and $\left.\mathrm{CaCl}_{2}\right)$ and detergent solutions used for cleaning (e.g., streets), which introduce chloride ions. In Kraków, high levels of gaseous and particulate pollutants are still a typical feature (Raporty o stanie środowiska w województwie małopolskim; Marszałek, 2016). Although since the 1990s, the concentration of pollutants is on decline, Kraków is still one of the European cities with the most polluted atmosphere. This is a consequence of its unfavourable atmospheric conditions, which include weak winds, temperature inversions, fogs (Matuszko et al., 2015), as well as the presence of large industrial centres and fossil fuel burning. Additionally, the level of pollutants is increased by distant industrial emissions brought by prevalent westerly winds from neighbouring regions. Road transport also contributes its share, notably in the dense structural layout of the Kraków Old Town. Other extrinsic sources of ions for precipitated salts could be animal (e.g., excrements of birds, like pigeons in Kraków) and microbiological activities, as well as capillary rise of ground and soil waters.

The intrinsic, natural and anthropogenic, sources of ions include weathering and leaching of the components of stones and other construction materials used, as well as chemicals added during conservation procedures.

The main sources of calcium for precipitated gypsum are building materials themselves. Calcium carbonate can be dissolved in the reaction with atmospheric $\mathrm{CO}_{2}$ at high humidity (forming $\mathrm{Ca}^{2+}$ and $\mathrm{HCO}_{3}^{-}$ions), and reprecipitated when water evaporates. In the presence of acid air pollutants (e.g., $\mathrm{SO}_{2}$ ), calcium sulphate, mainly gypsum, crystallizes not only on the surface of the stone. In case of the fine-grained Pińczów limestone (elevation of the Myszkowskis Chapel), the structure of the pore spaces additionally favours capillary condensation (pores < 0.1 and $0.1-1 \mu \mathrm{m}$ make up 59.51\%; Fig. 4) and circulation of hydrous solutions in the rock pores. Taking into account the average air humidity in Kraków of $77 \%$, the Pińczów limestone often remained saturated with acid water solutions, which could effectively dissolve fine-grained stone (Kozłowski et al., 1990). Partial evaporation of pore solution near the surface leads to its concentration, and when it reaches the saturation point, crystallization of salts occurs (see concentration of sulphur within a cross-section of the limestone; Fig. 3).

Cement renders covering stone blocks as well as mortars between the blocks can release $\mathrm{Ca}^{2+}, \mathrm{Na}^{+}, \mathrm{K}^{+}$, as well as $\mathrm{SO}_{4}^{2-}$, $\mathrm{CO}_{3}^{2-}$ and $\mathrm{Cl}^{-}$ions, and contribute to the stone deterioration. Materials used for conservation processes, e.g. water glass or barium water, have to be also mentioned as possible sources of
$\mathrm{Na}, \mathrm{Ca}$ and $\mathrm{Ba}$ ions (Doehme and Price, 2010; Domasłowski, 1993). Despite lack of information on previous conservation works, their contribution seems to be very likely, although it cannot be verified. Dominance of sodium and potassium salts in the efflorescences (thenardite/mirabilite, aphthitalite and darapskite) suggests that the sources of these cations could be both cement mortars and sandstone blocks (these cations can be released from weathering feldspars, micas and clay minerals). The same sources of cations should be considered in the case of nitre and nitratine traces, detected on the surface of some stone blocks.

\section{CONCLUSIONS}

The study has allowed detecting and determining the following hydrated and anhydrous compounds: simple salts of the divalent and monovalent cations - gypsum $\mathrm{CaSO}_{4} \cdot 2 \mathrm{H}_{2} \mathrm{O}$ and thenardite/mirabilite $\mathrm{Na}_{2} \mathrm{SO}_{4} / \mathrm{Na}_{2} \mathrm{SO}_{4} \cdot 10 \mathrm{H}_{2} \mathrm{O}$, a double sodium/potassium salt - aphthitalite $(\mathrm{K}, \mathrm{Na})_{3} \mathrm{Na}\left(\mathrm{SO}_{4}\right)_{2}$, and a double sulphate/nitrate salt darapskite $-\mathrm{Na}_{3}\left(\mathrm{SO}_{4}\right)\left(\mathrm{NO}_{3}\right) \cdot \mathrm{H}_{2} \mathrm{O}$. The anhydrous simple salts: halite $\mathrm{NaCl}$, nitratine $\mathrm{NaNO}_{3}$ and nitre $\mathrm{KNO}_{3}$ have been seldom encountered and observed. Other salts detected include ettringite $\mathrm{Ca}_{6} \mathrm{Al}_{2}\left(\mathrm{SO}_{4}\right)_{3}(\mathrm{OH})_{12} \cdot 26 \mathrm{H}_{2} \mathrm{O}$ and monosulphite $\mathrm{Ca}_{4} \mathrm{Al}_{2} \mathrm{O}_{6} \mathrm{SO}_{3} \cdot 11 \mathrm{H}_{2} \mathrm{O}$.

Gypsum, halite, nitratine and nitre are present on the surface and/or in pores of the materials analysed, whereas thenardite/mirabilite, aphthitalite and darapskite form efflorescences on the border between the limestone blocks and the cement mortar in the exposed part of the foundations.

As regards the cations, the salt distribution clearly reflects the chemical composition of the substrate on which and/or within they crystallize. Calcium salt, gypsum, was primarily observed in relation to the limestones: large concentrations were found in the Pińczów limestones and substantially lower amounts in the Jurassic limestones. It was also encountered in sandstones and cement replacements and joints. Calcium and aluminium salts (ettringite and monosulphite) are associated with the Portland cement render. They could be primary hydration products in such cement, but could also precipitate at the exposition of the cement to the atmospheric $\mathrm{SO}_{2}$ in the polluted environment of Kraków.

Diversity of the secondary salt distribution (in the form of crusts and efflorescences, and/or inside the materials, in pores) should be linked to the differences in the structure of the pore spaces, susceptibility of the material to the crystallization of salts, and capillary condensation. An explanation plausible for the minor occurrences of halite, nitre and nitratine in the elevation of the chapel could be related to the high solubility and migration of these salts in the masonry - more soluble salts are encountered at higher levels. Sources of potassium and sodium should be connected with the cement render covering some of the limestone architectonic elements. The sulphate and sulphate/nitrate salts of sodium and potassium - thenardite/mirabilite, aphthitalite and darapskite, present only in the form of efflorescences (in some parts of the foundations), seem to be related mostly to the components of the cement mortars in replacements and joints; however, the sandstone blocks and the possible past conservation procedures cannot be ruled out. The location of the efflorescences on the border between the Jurassic limestone blocks and the cement mortar reflects the porous structure of the materials. 
Formation of all the recognized and above-presented secondary salts resulted in the signs of deterioration of the Myszkowkis Chapel elevation. Unfortunately, although emission of some pollutants has been substantially reduced, concentrations of some others are increasing, e.g. ozone $\left(\mathrm{O}_{3}\right)$ and hydroxyl radical ( $\mathrm{HO} \cdot)$. As they are the most common atmospheric oxidation agents, which could oxidize ammonia, $\mathrm{NO}_{x}$ to $\mathrm{NO}_{3}^{-}$, and $\mathrm{SO}_{\mathrm{x}}$ to $\mathrm{SO}_{4}^{2-}$, especially in urban areas, an increase of concentrations of nitrate and sulphate salts is still possible in the atmosphere and other environments.

Acknowledgments. This work has been financially supported by the AGH University of Science and Technology, stat- utory grant No. 16.16.140.315. The authors acknowledge the support of B. Polczyński and K. Bałaga in sampling the historic monument, and G. Machowski, E. Pstrucha and A. Pstrucha from the Mercury Porosimetry Laboratory, AGH-UST, for performing mercury porosimetry measurements. We also thank the anonymous Reviewers for their helpful comments and suggestions. Author contributions: M.M. performed most of the measurements and their interpretation, wrote the manuscript and prepared most of the figures, K.D. assisted with the O.M. analyses of the stones, outlined the history of the Myszkowskis Chapel, and helped to improve the English version of the manuscript, A.G. performed XRPD analyses and prepared some of the figures, J.Cz. assisted with the O.M. analyses of the stones.

\section{REFERENCES}

Adamski, G., Bratasz, L., Kozlowski, R., Mayr, N., Mucha, D. Stilhammerova, M., Weber, J., 2009. Roman cement - key historic material to cover the exteriors of buildings. In: RILEM Workshop Repair Mortars for Historic Masonry (ed. C. Groot): 2-11. RILEM Publications SARL.

Benavente, D., 2011. Why pore size is important in the deterioration of porous stones used in the built heritage. Macla, 15: 41-42.

Bieniarzówna, J., Małecki, J.M., 1984. Dzieje Krakowa, tom 2, Kraków w wiekach XVI-XVIII (in Polish). Wydawnictwo Literackie, Kraków.

Boggs, S., Jr., 2010. Petrology of Sedimentary Rocks. Cambridge University Press, Cambridge.

Bromowicz, J., Górniak, K., Przystaś, G., Rembiś, M., 2001. Results of petrographic analyses of typical reservoir lithofacies of the Carpathian Flysch (in Polish with English abstract). Polish Journal of Mineral Resources, 4: 31-75.

Buzgar, N., Buzatu, A., Sanislav, I.V., 2009. The Raman study on certain sulfates. Analele Ştiinţifice ale Universităţii "Al.I. Cuza" din Iaşi, seria Geologie, 55: 5-23.

Cardell, C., Delalieux, F., Roumpopoulos, K., Moropoulou, A. Auger, F., Van Grieken, R., 2003. Salt-induced decay in calcareous stone monuments and buildings in a marine environment in SW France. Construction and Building Materials, 17: 165-179.

De Belie, N., 2010. Microorganisms versus stony materials: a love-hate relationship. Materials and Structures, 43 1191-1202.

De Clercq, H., Jovanović, M., Linnow, K., Steiger, M., 2013. Performance of limestones laden with mixed salt solutions of $\mathrm{Na}_{2} \mathrm{SO}_{4}-\mathrm{NaNO}_{3}$ and $\mathrm{Na}_{2} \mathrm{SO}_{4}-\mathrm{K}_{2} \mathrm{SO}_{4}$. Environmental Earth Science, 69: 1751-1761.

Del Monte, M., Ausset, P., Lefèvre, R.A., Thiébault, S., 2001. Evidence of pre-industrial air pollution from the Heads of the Kings of Juda statues from Notre Dame Cathedral in Paris. Science of the Total Environment, 273: 101-109.

Dobrowolski, T., 1978. Sztuka Krakowa (in Polish). Wydawnictwo Literackie, Kraków.

Doehme, E., Price, C. A., 2010. Stone Conservations: An Overview of Current Research. Getty Conservation Institute, Los Angeles.

Domasłowski, W., 1993.Profilaktyczna konserwacja kamiennych obiektów zabytkowych (in Polish). Wydawnictwo Uniwersytetu Mikołaja Kopernika, Toruń.

Flatt, R.J., Steiger, M., Scherer, G.W., 2007. A commented translation of the paper by C.W. Correns and W. Steinborn on crystallization pressure. Environmental Geology, 52: 187-203.

Gosselin, C., Girardet, F., Feldman, S.B., 2012a. Compatibility of Roman cement mortars with gypsum stones and anhydrite mortars: the example of Valère Castle (Sion, Switzerland). 12th In- ternational Conference on the Deterioration and Conservation of Stone: 1-11. Columbia University, New York.

Gosselin, C., Scrivener, K.L., Feldman, S.B., 2012b. Hydration of roman cements used for architectural restoration. International Conference on Cement Chemistry, Madrid 2011: 1-13.

Grabski, W., Nowak, J., 1957. Problem niszczenia się kamienia w budowlach zabytkowych Krakowa (in Polish). Materiały budowlane, 1: 33-39.

Grabski, W., Nowak, J., 1960. Studia technologiczne i mineralogiczne nad wapieniem pińczowskim (Objawy i przyczyny zniszczeń kamienia przy kopule kaplicy Myszkowskich kościoła OO. Dominikanów w Krakowie) (in Polish), manuscript, 26 pp. Archive of Kraków City Office, Department of Conservation of Monuments, No inv. 3126/77.

Gradziński, R., 1972. Przewodnik geologiczny po okolicach Karkowa (in Polish). Wyd. Geol., Warszawa.

Górecki, J., Sermet, E., 2010. Quarries of Kraków - an underestimated heritage (in Polish). In: Mining History - an Element of the European Cultural Heritage (eds. P.P. Zagożdżon and M. Madziarz), 3: 123-138. Oficyna Wydawnicza Politechniki Wrocławskiej.

Grossi, C.M., Brimblecombe, P., Menéndez, B., Benavente, D., Harris, I., Déqué, M., 2011. Climatology of salt transitions and implications for stone weathering. Science of the Total Environment, 409: 2577-2585.

Hamilton, A., Menzies, R., 2010. Raman spectra of mirabilite $\mathrm{Na}_{2} \mathrm{SO}_{4} \cdot 10 \mathrm{H}_{2} \mathrm{O}$ and the rediscovered metastable heptahydrate, $\mathrm{Na}_{2} \mathrm{SO}_{4} \cdot 7 \mathrm{H}_{2} \mathrm{O}$. Journal of Raman Spectroscopy, 41: 1014-1020.

Hansteen, E.T., Burke, E., 1994. Aphthitalite in hight-temperature fluid inclusions in quartz from Eikeren-Skrim granite complex the Oslo paleorift. Norsk Geologisk Tidsskrift, 74: 238-240.

Holtkamp, M., Heijnen, W., 1991. The mineral darapskite in the efflorescence on two Dutch Churches. Studies in Conservation, 36: 175-178.

Jentzsch, P.V., Ciobota, V., Kampe, B., Rösch P., Popp J., 2012. Origin of salt mixtures and mixed salts in atmospheric particulate matter. Journal of Raman Spectroscopy, 43: 514-519.

Kozłowski, R., Hughes, D., Weber, J., 2010. Roman cements: key materials of the built heritage of the 19th century. In: Materials, Technologies and Practice in Historic Heritage Structures (eds. M. Bostenaru Dan, R. Přikryl and A. Török): 259-277. Springer Science+Business Media B.V.

Kozłowski, R., Magiera, J., Weber, J., Haber, J., 1990. Decay and conservation of Pinczów porous limestone. I. Lithology and weathering. Studies in Conservation, 35: 205-221.

Kramar, S., Urosevič, M., Pristacz, H., Mirtič, B., 2010. Assessment of limestone deterioration due to salt formation by mi- 
cro-Raman spectroscopy: application to architectural heritage. Journal of Raman Spectroscopy, 41: 1441-1448.

Labus, M., 1998. Water soluble salt in degradation processes of stony architectural monuments in the Upper Silesia. Geological Quarterly 42 (2): 209-220.

Lindström, N., Heitmann, N., Linnow, K., Steiger, M., 2015. Crystallization behavior of $\mathrm{NaNO}_{3}-\mathrm{Na}_{2} \mathrm{SO}_{4}$ salt mixtures in sandstone and comparison to single salt behavior. Applied Geochemistry, 63: 116-132.

Linnow, K., Steiger, M., Lemster, Ch., De Clercq, H., Jovanović, M., 2013. In situ Raman observation of the crystallization in $\mathrm{NaNO}_{3}-\mathrm{Na}_{2} \mathrm{SO}_{4}-\mathrm{H}_{2} \mathrm{O}$ solution droplets. Environmental Earth Science, 69: 1609-1620.

Łagosz, A., Małolepszy, J., 2003. Tricalcium aluminate hydration in the presence of calcium sulfite hemihydrates. Cement and Concrete Research, 33: 333-339.

Manecki, A., Marszalek, M., Schejbal-Chwastek, M., Skowroński, A., 1997. Stone decay in some historic buildings of Kraków (Poland) and its reasons. Folia Facultatis Scientiarum Universitatis Masarykianae Brunensis, Geologia 39:149-156.

Marszałek, M., 2016. Identification of secondary salts and their sources in deteriorated stone monuments using micro-Raman spectroscopy, SEM-EDS and XRD. Journal of Raman Spectroscopy, 47: 1473-1485.

Marszałek, M., Alexandrowicz, Z., Rzepa, G., 2014. Composition of weathering crusts on sandstones from natural outcrops and architectonic elements in an urban environment. Environmenta Science and Pollutution Research, 21: 1423-1436.

Matuszko, D., Piotrowicz, K., Kowanetz, L., 2015. Components of the natural environment - climate (in Polish with English summary). In: Natural Environment of Krakow. Resources - Protection - Management (eds. M. Baścik and B. Degórska): 81-108. Uniwersytet Jagielloński w Krakowie, Kraków.

Morillas, H., Marcaida, I., Maguregui, M., Carrero, J.A., Madariaga, J.M., 2016. The influence of rainwater composition on the conservation state of cementitious building materials. Science of the Total Environment, 542: 716-727.

Pintér, F., Gosselin, C., 2018. The origin, composition and early age hydration mechanisms of Austrian natural Portland cement. Cement and Concrete Research, 110: 1-12.

Pintér, F., Vidovszky, I., Weber, J., Bayer, K., 2014. Mineralogical and microstructural characteristics of historic Roman cement renders from Budapest, Hungary. Journal of Cultural Heritage, 15: 219-226.

Prieto-Taboada, N., Gómez-Laserna, O., Martínez-Arkarazo, I., Olazabal, Á.M., Madariaga, J.M., 2014. Raman spectra of the different phases in the $\mathrm{CaSO}_{4}-\mathrm{H}_{2} \mathrm{O}$ system. Analytical Chemistry, 86: 10131-10137.

Prieto-Taboada, N., Fdez-Ortiz de Vallejuelo, S., Veneranda Fdez-Ortiz de Vallejuelo, S., Veneranda, M., Madariaga, J.M., 2019. The Raman spectra of the $\mathrm{Na}_{2} \mathrm{SO}_{4}-\mathrm{K}_{2} \mathrm{SO}_{4}$ system: applicability to soluble salts studies in built heritage. Journal of Raman Spectroscopy, 50: 175-183.

Přikryl, R., Přikrylová, J., Racek, M., Weishauptová, Z., Kreislova, K., 2017. Decay mechanism of indoor porous opuka stone: a case study from the main altar located in the St. Vitus Cathedral, Prague (Czech Republic). Environmental Earth Science, 76: 1-15.

Puşcaş, C.M., Onac, B.P., Tămas, T., 2010. The mineral assemblage of caves within Şălitrari Mountain (Cerna Valley, SW Romania): depositional environment and speleogenetic implications. Carbonates Evaporites, 25: 107-115.

Rajchel, J., 2004. Kamienny Kraków (in Polish). Uczelniane Wydawnictwa Naukowo-Dydaktyczne AGH, Kraków.
Raporty o stanie środowiska w województwie małopolskim (in Polish). Wojewódzki Inspektorat Ochrony Środowiska w Krakowie, Kraków. http//www.krakow.pios.gov.pl Accessed December 2018.

Rembiś, M., Smoleńska, A., 2010. Resistance of selected Carpathian sandstones to salt crystallization and the changes of their microstructures. Mineral Resources Management, 26: 37-59.

Rodriguez-Navarro, C., Doehme, E., 1999. Salt weathering: influence of evaporation rate, supersaturation and crystallization pattern. Earth Surface Processes and Landforms, 24: 191-209.

Rożek M., 2009. Urbs celeberrima. Przewodnik po zabytkach Krakowa (in Polish). WAM, Kraków.

Sabbioni, C., 2003. Mechanisms of air pollution damage of stone. In: The Effects of Air Pollution on the Built Environment (ed. P. Brimblecombe): 63-106. Air Pollution Reviews, 2nd vol. Imperial College Press, London.

Sadezky, A., Muckenhumber, H., Grothe, H., Niessner, R., Pöschl, U., 2005. Raman microspectroscopy of soot and related carbonaceous materials: spectral analysis and structural information. Carbon, 43: 1731-1742.

Silcock, H.L., 1979. Solubilities of inorganic and organic compounds. Ternary and Multicomponent Systems of Inorganic Substances, 3. Pergamon Press, Oxford.

Słaby, E., Galbarczyk-Gąsiorowska, L., Trzciński, J., Górka, H., Łukaszewski, P., Dobrowolska, A., 2000. The mechanism of sandstone deterioration caused by salt crystallisation (in Polish with English abstract). Przegląd Geologiczny, 49:124-133.

Snethlage, R., Sterflinger, K., 2011. Stone conservation. In: Stone in Architecture (eds. S. Siegesmund and R. Snethlage): 411-544. Springer-Verlag, Berlin, Heidelberg.

Steiger, M., Asmussen, S., 2008. Crystallization of sodium sulfate phases in porous materials: the phase diagram $\mathrm{Na}_{2} \mathrm{SO}_{4}-\mathrm{H}_{2} \mathrm{O}$ and the generation of stress. Geochimica et Cosmochimica Acta, 72: 4291-4306.

Studencki, W., 1988. Facies and sedimentary environment of the Pinczow Limestones (Middle Miocene; Holy Cross Mountains Central Poland). Facies, 18: 1-26.

Suh, J., Sung Yumb, W., Jeong, Y., Park H.G., Eun Oh, J., 2019 The cation-dependent effects of formate salt additives on the strength and microstructure of $\mathrm{CaO}$-activated fly ash binders. Construction and Building Materials, 194: 92-101.

Szeląg, H., Garbacik, A., Pichniarczyk, P., Baran, T., 2008. Cement romański i jego właściwości. (in Polish). Surowce i Maszyny Budowlane, 1: 74-78.

Szelagg, H., Garbacik, A., Pichniarczyk, P., Baran, T., 2009. Contemporary Roman cement and its properties (in Polish with English abstract). Budownictwo, Czasopismo techniczne, Wydawnictwo Politechniki Krakowskiej, 109: 2-B, 337-345.

Ślączka, A., Kamiński, M.A., 1998. A guide book to excursions in the Polish flysch Carpathians. Grzybowski Foundation Special Publication, 6.

Török, A., Licha, T., Simon, K., Siegesmund, S., 2011. Urban and rural limestone weathering; the contribution of dust to black crust formation. Environmental Earth Science, 63: 675-693.

Weber, J., Gadermayr, N., Kozłowski, R., Mucha, D., Hughes, D., Jaglin, D., Schwarz, W., 2007. Microstructure and mineral composition of Roman cements produced at defined calcination conditions. Materials Characterisation, 58: 1217-1228.

Wilczyńska-Michalik, W., 2004. Influences of atmospheric pollution on the weathering of stones in Kraków monuments and rock outcrops in Kraków, Kraków-Częstochowa Upland and the Carpathians. Akademia Pedagogiczna w Krakowie, Prace Monograficzne, 377. 